\title{
Application of Frankincense and Rice Starch as Eco- Friendly Substances for the Resizing of Paper as a Conservation Practice
}

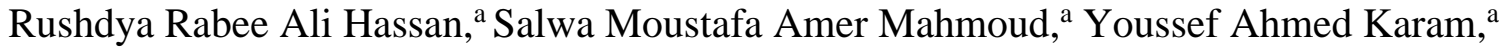 \\ Shaimaa Mohamed Salah, ${ }^{\text {a }}$ Sara Yousef Ebrahim, ${ }^{\text {a }}$ Mahmoud Adel Abdelwahab, ${ }^{\mathrm{a}}$ \\ Al-Hussein Muhammad Hassan Ahmed, ${ }^{\mathrm{a}}$ Hayssam M. Ali, ${ }^{\mathrm{b}}$ Martin Böhm, ${ }^{\mathrm{c}}$ and \\ Mohamed Z. M. Salem ${ }^{\text {d,* }}$
}

\begin{abstract}
Smart, environmentally friendly alternatives, i.e., frankincense and rice starch, are recommended for usage in modern paper conservation processes during the re-sizing process treatments. Different concentrations of frankincense and rice starch were applied to paper samples before and after ageing. Multiple analysis methods were performed to ensure the effectiveness of these materials. Promising results were found, but at varying degrees according to the type and concentration of the materials. Scanning electron microscopy illustrated that the frankincense particles were completely absorbed into the cell walls after ageing. Results indicated that there was no considerable change in $\mathrm{pH}$ before and after treatment or ageing; the best results for decreasing the acidity utilized a treatment with a mixture of frankincense and rice starch in a 2 to 1 ratio $\left(F_{2} S_{1}\right)$. Fourier transform infrared spectroscopy illustrated an increased $\mathrm{CH}_{2}$ region and decreased $\mathrm{OH}$ stretching as a result of the bonds formed from the starch and crystals formed by frankincense, which agreed with the increased coating and strength of the paper fibers. The total color change values of all the treated samples after ageing were less than 4.5 . Frankincense was found to provide strength in supporting wood fibers.
\end{abstract}

Keywords: Wood pulp; Paper; Resizing; Ageing; Frankincense; Starch; FTIR; SEM

Contact information: a: Conservation Department, Faculty of Archaeology, Cairo University, Giza 12613 Egypt; b: Botany and Microbiology Department, College of Science, King Saud University, P.O. Box 2455, Riyadh 11451 Saudi Arabia; c: Department of Materials Engineering and Chemistry, Faculty of Civil Engineering, Czech Technical University in Prague, Thákurova 7, 16629 Prague 6 Czech Republic; d: Forestry and Wood Technology Department, Faculty of Agriculture (El-Shatby), Alexandria University, Alexandria 21545 Egypt; *Corresponding Author: zidan_forest@yahoo.com

\section{INTRODUCTION}

Plant sources such as cotton, flax, jute fibers, ramie, and finally wood-derived fibers have been the main source for paper making from the beginning of its invention until the present time (Dillen et al. 2016). However, its method of manufacture is quite different, since paper forms as a layer when a suspension of disintegrated paper pulp is allowed to settle, and the water is drained off (Taha et al. 2019; Hassan et al. 2021). The invention of paper is credited to the Chinese (Hassan et al. 2020). Plant fibers are the most commonly used material for paper manufacturing and at present, these come from wood pulp. However, before the $20^{\text {th }}$ century, linen and cotton rags were used. Wood pulp is the principal fibrous raw material from which paper is made, of which cellulose, the major 
component of papermaking fibers, contributes $40 \%$ to $45 \%$ of the dry weight of the wood. In addition, wood paper is composed of cellulose, lignin, hemicellulose, and some extractives (Bajpai 2018).

Paper exposes many factors contributing to deterioration factors, and these can be divided into three categories: 1) physical factors, which include moisture, temperature, and light (Hassan et al. 2020). These effects affect paper during droughts and humid periods, which results in fragility, microorganism growth, acceleration of chemical reactions, changes in dimensions, and shrinking and swelling (Moncmanová 2007; Hassan 2015); 2) chemical factors, which include gaseous pollutants and salts that increase the degree of acidity and results in oxidation-reduction reactions (Hassan et al. 2020); and 3) biological factors, e.g., insects, rodents, fungi, and bacteria (Bankole 2010; Mansour et al. 2017). The effect of biological factors is summarized in cellulose hydrolysis, pigment stain, as well as the loss of portions of the paper and holes (Björdal et al. 1999; Björdal 2012; Liu et al. 2018). Since these deterioration factors occur in paper, there are natural materials, e.g., gelatin, natural extracts, plant biomass, and glue, and synthetic materials, e.g., methyl cellulose, polyvinyl alcohol, and methyl hydroxy ethyl cellulose, that are used for the resizing of paper (Evetts et al. 1989; Spitzmueller 1992; Ravines and Faurie 1993; Kolbe 2004; Ardelean et al. 2007; Baker 2007; Hummert et al. 2013; Ciolacu et al. 2017; Mohamed et al. 2019; Salim et al. 2020; Hassan et al. 2021; Mansour et al. 2021a,b; Taha et al. 2021). The term re-sizing means that the historical manuscripts and documents are covered with an aqueous solution of the sizing agent. The original sizing agents, applied to paper during the initial manufacturing, tend to decompose with time. Therefore, conservators routinely replace or supplement the lost sizing agent by natural or synthetic materials called resizing agents.

Gelatin is a protein obtained from the hard and soft connective tissues of animals. It became used for paper treatment in the second half of the 13th century (Pataki 2009). It was used to prevent the bleeding of inks, as well as for its ability to improve various properties of paper, e.g., its strength and resistance to degradation and contamination. It also plays a beneficial role at the molecular level by neutralizing the rate of cellulose degradation due to ageing (Missori et al. 2006; Irvine et al. 2015; Huang et al. 2018).

Animal gums are produced from a wide range of animal tissues, e.g., leather, bones, etc. The gums are proteins that consist of many amino acids. There are also types of vegetable glue, and a $25 \%$ solution of vegetable glue in water was used as a sizing solution for paper. These substances also have been used in painting media, coatings and grounds, in the gilding of illuminated manuscripts, and pastel fixatives (Missori et al. 2006). Paraloid B-72 (Acryloid) is one of the most frequently used acrylic polymers, employed for several object arts, as well as to wood and paper to improve their mechanical characteristics (Pataki 2009; Mansour et al. 2015; Mansour and Salem 2015; Vinçotte et al. 2019; Abo Elgat et al. 2020; Kovács et al. 2021).

Some synthetic chemicals are useful for the sizing of paper. The idea is that these synthetic chemicals dissolve in organic solvents and do not affect the ink. These synthetic chemicals include soluble nylon, which is a form of nylon called methyl methoxynylon. This chemical is soluble in methyl alcohol, ethyl alcohol, or methylated spirits, hence the name soluble nylon (Agrawal and Barkeshli 1997). Methylcellulose, unlike glue and gelatin, is soluble in cold water. It is also soluble in some organic solvents, e.g., dimethylformamide and dimethylsulphoxide. One great advantage of methylcellulose is its resistance to the growth of fungus (Nasatto et al. 2015). Methyl hydroxyethyl cellulose, which has some very desirable properties, can be dissolved in water and has also been used 
as a resizing material (Agrawal and Barkeshli 1997). The mechanical properties between paper components can be improved by increasing the crosslinking between the cellulose fibers, which has been achieved with several polymers, e.g., cellulose acetate, polymethyl acrylate, and phenol-formaldehyde resin solutions (Manjunath and Sailaja 2014; Saha et al. 2016; Meesorn et al. 2017; Kumar et al. 2021). Cationic starch, polyacrylamide, and polyvinyl alcohol (PVA) have also been used for the sizing of paper (Liu et al. 2010; Hassan and Mohamed 2017; Seo et al. 2020; Xia et al. 2020).

Currently, with trends heading toward green methods that are utilized to help preserve the environment, the use of eco-friendly materials is more prevalent. These materials maintain the health of conservator specialists, are harmless to the environment, and are safe to use. As such, rice starch and frankincense have been considered for study in terms of paper resizing.

Pure starch generally contains, by weight, $20 \%$ to $25 \%$ amylose and $75 \%$ to $80 \%$ amylopectin (Brown and Poon 2016). Historically, a pure extracted wheat starch paste was possibly used in Ancient Egypt to glue papyrus. More recently, it has been used in the paper industry for its strong bonding properties between the pulp fibers. The starch works to strengthen the paper and provide it resistance to water absorption, in addition to increasing paper smoothness and improving printing properties. As such, it is used for the surface treatment of paper (Hunter 1978; Hubbe and Bowden 2009).

The structure and the properties of starch are well known, and there is considerable usage throughout history of starch as an eco-friendly resizing material. One of the disadvantages of using starch as a re-sizing material is that it is an attractive substance for microbiological deterioration. In addition, it can also cause color change.

Frankincense obtained from Boswellia trees (family Burseraceae), particularly Boswellia sacra Flueck. is primarily composed of a mucus-like cluster (12\% to 23\%), essential oil (5\% to 15\%), and a lipophilic part (55\% to 66\%). This composition has shown quite a bit of variation, depending on the species and grade of the resin. Frankincense contains volatile compounds, with more than 20 monoterpenes and 28 sesquiterpenes. The lipophilic parts are composed of terpenoids, including Boswellia acids (BAs), which are the chemotaxonomic markers of Boswellia (Ali et al. 2008; El-Nagerabi et al. 2013; AlHarrasi et al. 2019; Rajabian et al. 2020). This substance has been used throughout history in medicine, herbalism, etc., but until now it has not been used in the field of archaeology. In view of these different and promising components of frankincense, it was presented as a re-sizing agent in this study, as it contains resinous materials similar in properties to gum Arabic, which can provide the protection coating and strengthening required for damaged paper, in addition to its anti-oxidation properties (Al-Harrasi et al. 2013). As such, it has been chosen for this project to determine whether it is suitable for use as an eco-friendly re-sizing material applied to paper. Furthermore, many studies have reported its anticancer, anti-inflammatory, immunomodulatory, and antimicrobial properties (Al-Yasiry and Kiczorowska 2016). Re-sizing of ancient paper depends on the use of gelatin or industrial cellulose derivatives, each of which carries many defects. Therefore, the current study is promising in terms of incorporating new natural components in the field of manuscript restoration, and even in the field of papermaking. Thus, frankincense and rice starch were employed for first time in such treatments. This may effectively address the defects of traditional resizing materials and enhance the chemical properties of wood paper fibers.

The aim of this study is to propose and evaluate new materials for resizing paper manuscripts using eco-friendly materials and to demonstrate the effectiveness of these materials by using a set of examinations, i.e., digital and scanning electron (SEM) 
microscopy, in addition to Fourier transform infrared spectroscopy (FTIR), $\mathrm{pH}$ measurements, and color change measurements.

\section{EXPERIMENTAL}

\section{Samples and Artificial Ageing}

A group of sulfate pulp paper sheets $\left(40 \mathrm{~g} / \mathrm{m}^{2}\right)$ were brought from the Egyptian National Library and Archives and were exposed to artificial ageing at the National Institute of Standards (NIS), Giza, Egypt for this study. The artificial ageing process (both before and after treatment) was at a temperature of $80{ }^{\circ} \mathrm{C}$ and a relative humidity of $65 \%$ that lasted for 5 days. This was equivalent to 25 years of natural ageing according to ISO standard 5630-3 (1996). Afterwards, six samples were cut from the paper sheets with $5 \mathrm{~cm}$ $\times 10 \mathrm{~cm}$ dimensions.

\section{Preparation of the Iron Gall Ink and Gum Arabic}

The ink was prepared by adding gallic acid and tannic acid with some grains of ferrous sulfate to distilled water, after which gum Arabic was added (Jančovičová et al. 2007). The gum Arabic was prepared by grinding the crystals and then melting them in a hot water bath at a temperature of $80^{\circ} \mathrm{C}$ and stirring until complete melting; the mixture was then filtered to remove impurities (Hidalgo et al. 2018). The iron gall ink was applied to the six previously cut samples with a brush to the one half of the samples, and the other half was left without ink. All samples were left out until they become completely dry, after which the different concentrations of the sizing materials were applied on the paper samples by brush (Figs. 1 and 2).

\section{Preparation of the Starch and Frankincense}

Rice starch was used as a resizing material and was produced by Al Mashreq Gardens for Trading and Distribution, Cairo, Egypt. It contains $5.95 \mathrm{~g}$ of protein, $1.42 \mathrm{~g}$ of fats, $80.13 \mathrm{~g}$ of carbohydrates, $10 \mathrm{~g}$ of calcium, and $0.35 \mathrm{~g}$ of iron. In addition to using rice starch as a resizing material, frankincense (Boswellia serrata) gum was also used, which was produced by Herbal House Centers Company.

Six rice starch $(\mathrm{S})$ and frankincense $(\mathrm{F})$ solutions were prepared with different concentrations (as shown in Table 1). Frankincense and starch were mixed to prepare different solutions according to the proportions in the table. The samples were prepared by applying various concentrations in $100 \mathrm{~mL}$ of distilled water and melted in a hot water bath by stirring these substances until complete melting and then filtered to remove any impurities. It should be noted that mixtures of rice starch and frankincense were employed without using either material alone for two reasons: 1) the common belief about the rapid decomposition of starch; and 2) the authors tested several primary samples with only starch and found the paper fibers became brittle, especially at high concentrations. Therefore, only mixtures of rice starch $(\mathrm{S})$ and frankincense $(\mathrm{F})$ were used. Note also that the highest concentration was $2 \%$. This was based on preliminary experiments. There was a pre-test to determine if a higher concentration would be better, but the test showed that concentrations higher than $2 \%$ for this material resulted in an increase of the viscosity of the solutions, and this hinders the application process and penetration into the paper structure. 
Table 1. Different Concentrations Used as Resizing Materials for the Treatment of Paper samples

\begin{tabular}{|c|c|c|c|c|}
\hline $\begin{array}{l}\text { Sample } \\
\text { Number }\end{array}$ & $\begin{array}{c}\text { Frankincense } \\
\text { Concentration (gm) }\end{array}$ & $\begin{array}{c}\text { Rice Starch } \\
\text { Concentration }(\mathrm{gm})\end{array}$ & $\begin{array}{l}\text { Dissolving solution } \\
\qquad(\mathrm{mL})\end{array}$ & $\begin{array}{l}\text { Surface area } \\
\text { for each } \\
\text { concentration }\end{array}$ \\
\hline 1 & 0.5 & 1.5 & \multirow{6}{*}{$\begin{array}{c}\text { All resizing } \\
\text { materials were } \\
\text { dissolved in } 100 \mathrm{~mL} \\
\text { of distilled water to } \\
\text { produce different } \\
\text { concentrations. }\end{array}$} & \multirow{7}{*}{$\begin{array}{l}\text { Each } \\
\text { concentration } \\
\text { in } 100 \mathrm{~mL} \\
\text { water applied } \\
\text { on surface } \\
1.84 \mathrm{~m}^{2}\end{array}$} \\
\hline 2 & 1 & 1 & & \\
\hline 3 & 1 & 2 & & \\
\hline 4 & 1.5 & 0.5 & & \\
\hline 5 & 1.5 & 1.5 & & \\
\hline 6 & 2 & 1 & & \\
\hline 7 & 1.75 & 0.25 & & \\
\hline
\end{tabular}
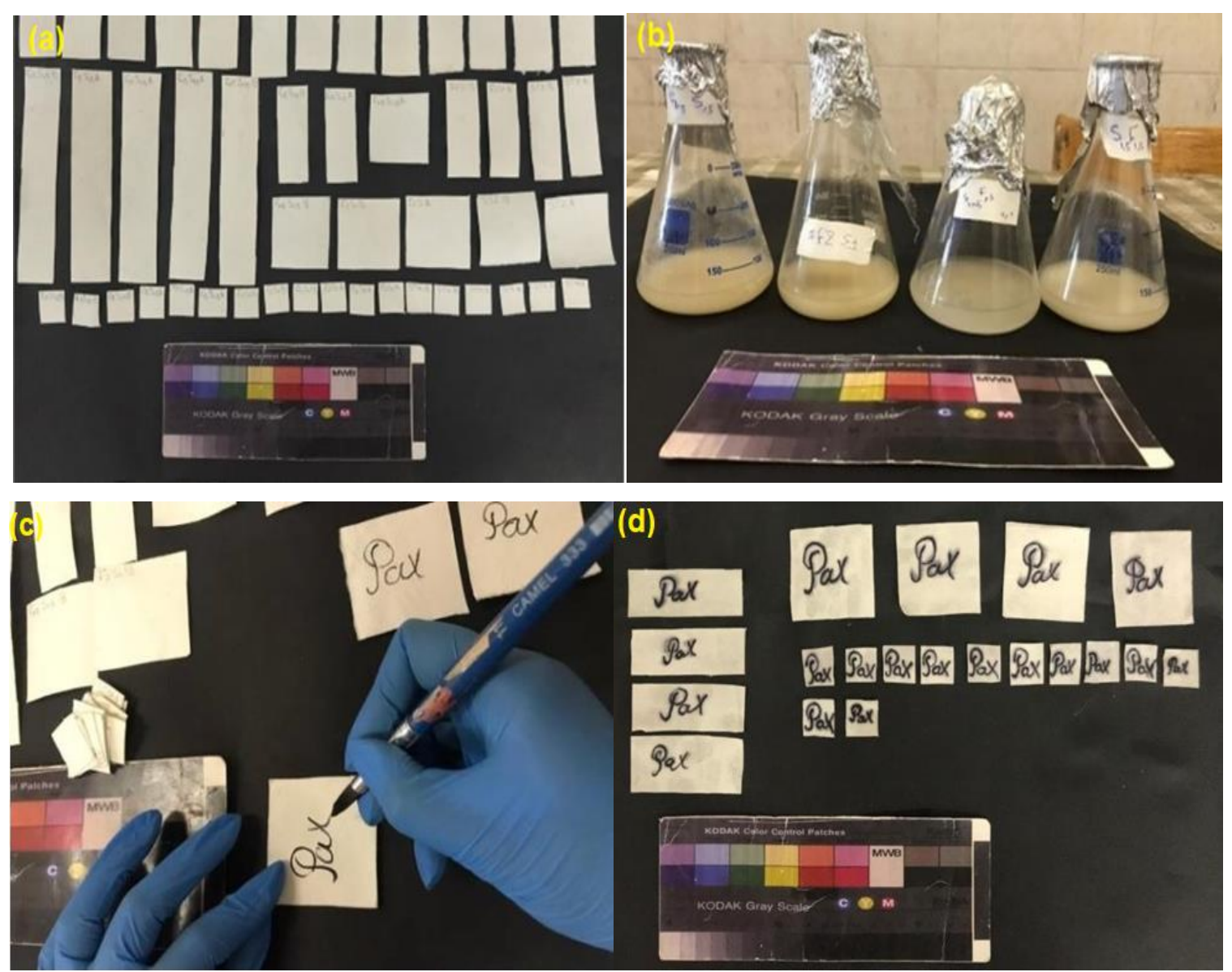

Fig. 1. Steps of the experimental study: (a) the cutting of samples; (b) the preparation of the treated materials; (c) writing with iron gall ink; and (d) the shapes of the samples after treatment.

After the application of ink to one side of the paper samples, the samples were exposed to heat for $3 \mathrm{~h}$ to determine the best treatment concentrations. The results showed that the samples with a high concentration of rice starch were missing water, resulting in solid content. Therefore, the concentrations $\mathrm{F}_{1.5} \mathrm{~S}_{1.5}, \mathrm{~F}_{1} \mathrm{~S}_{2}$, and $\mathrm{F}_{1} \mathrm{~S}_{1}$ were excluded (Egharevba 2019), while the concentration F2S1 showed the best result among other concentrations $\left(\mathrm{F}_{2} \mathrm{~S}_{1}-\mathrm{F}_{1.5} \mathrm{~S}_{0.5}-\mathrm{F}_{0.5} \mathrm{~S}_{1.5}\right)$. In addition, extra attention was given to the $\mathrm{F} 1.75 \mathrm{~S}_{0.25}$ treatment. Therefore, four concentrations were used to treat the paper samples (Fig. 1). 

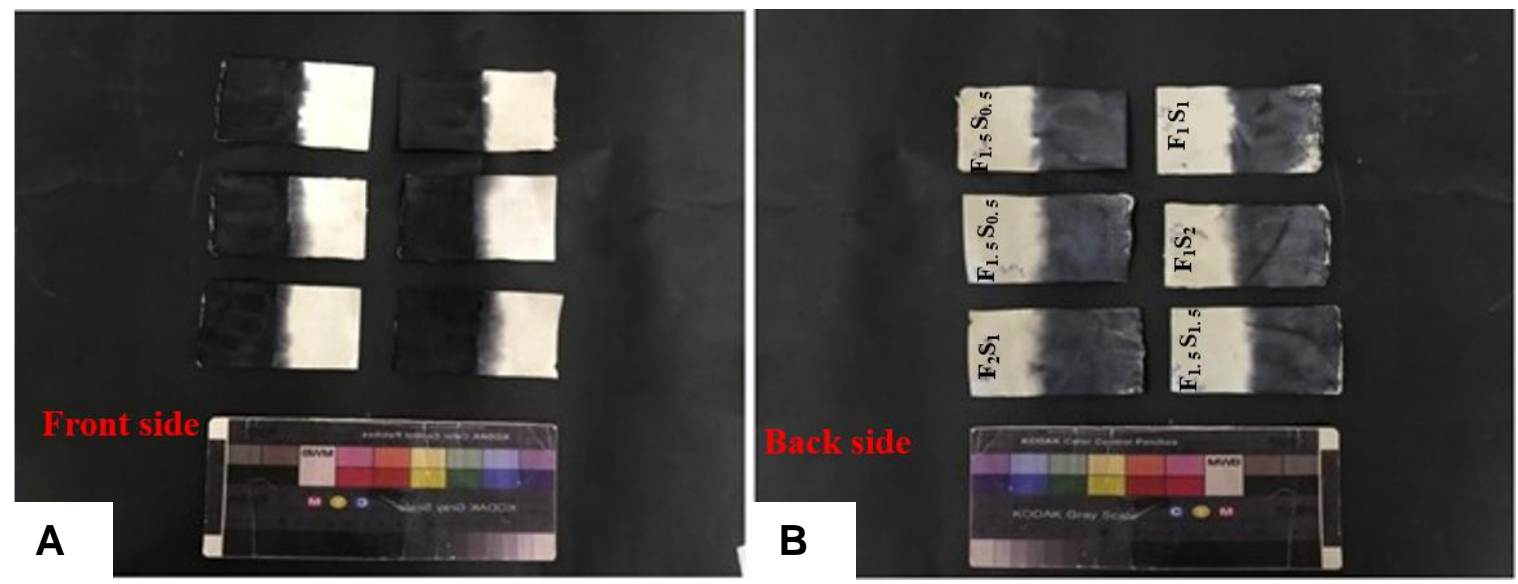

Fig. 2. The 6 samples after the application of ink and the treatment materials

Next, $2 \mathrm{~cm} \times 2 \mathrm{~cm}$ samples were cut from wood paper to be analyzed via SEM and infrared analysis. Samples with $5 \mathrm{~cm} \times 5 \mathrm{~cm}$ dimensions were cut and used in the universal serial bus (USB) microscope and color change analysis. In addition, the samples used for the $\mathrm{pH}$ analysis were cut to $2.5 \mathrm{~cm} \times 7.5 \mathrm{~cm}$. After that, the samples all had a Latin word (Pax, i.e., peace) written on them with iron gall ink. The treatment materials were applied at different concentrations $\left(\mathrm{F}_{2} \mathrm{~S}_{1}, \mathrm{~F}_{1.75} \mathrm{~S}_{0.25}, \mathrm{~F}_{1.5} \mathrm{~S}_{0.5}\right.$, and $\left.\mathrm{F}_{0.5} \mathrm{~S}_{1.5}\right)$, which were allowed to completely dry, and then half of the samples were exposed to artificial ageing (Fig. 2).

The concentrations used are as follows: $\mathrm{F}_{2} \mathrm{~S}_{1} \mathrm{~B}, \mathrm{~F}_{1.75} \mathrm{~S}_{0.25} \mathrm{~B}, \mathrm{~F}_{1.5} \mathrm{~S}_{0.5} \mathrm{~A}, \mathrm{~F}_{2} \mathrm{~S}_{1} \mathrm{~A}$, $\mathrm{F}_{0.5} \mathrm{~S}_{1.5} \mathrm{~A}, \mathrm{~F}_{0.5} \mathrm{~S}_{1.5} \mathrm{~B}, \mathrm{~F}_{1.75} \mathrm{~S}_{0.25} \mathrm{~A}$, and $\mathrm{F}_{1.5} \mathrm{~S}_{0.5} \mathrm{~B} . \mathrm{A}$ USB microscope and SEM microscope were used to examine the samples and to detect any changes that occurred in the treated samples before and after ageing. In addition, FTIR analysis, $\mathrm{pH}$ measurements, and color change measurements were in this study.

\section{Universal Serial Bus (USB) Digital Microscope}

A USB digital microscope (200x) (PZ01, Shenzhen Super Eyes Co., Ltd., Guangdong, China) was used for the visual assessment of the experimental samples.

\section{Scanning Electron Microscope}

The paper samples were examined using a JEOLJSM 5400LV EDX Link ISISOxford Detector High Vacuum), and the samples were coated with gold.

\section{pH Measurement}

The $\mathrm{pH}$ meter model, made in Romania, is a waterproof temp pocket tester with a replaceable probe. It is located at the lab of manuscripts, Faculty of Archaeology, Cairo University. The samples were cut into $50 \mathrm{~g}$ pieces for each treatment and placed into 40 $\mathrm{mL}$ of distilled water (a $\mathrm{pH}$ of 7 ) for $1 \mathrm{~h}$ to measure the paper acidity using the cold extraction method. However, the $\mathrm{pH}$ value was initially measured via a method at room temperature according to ASTM standard D778 - 97 (1997).

\section{Color Change Using the CIELAB System}

The colors of the samples were measured with an Optimatch 3100 (CE 3100, SDL, United Kingdom). All samples were measured in the visible region, i.e., in a wavelength range of 400 to $700 \mathrm{~nm}$, with an interval of $10 \mathrm{~nm}$, using a D65 light source and an observed 
angle of $10^{\circ}$. The colorimetric coordinates $L, a$, and $b$ of the CIELAB color space were used to express color change. The CIELAB color space is organized in a cubic form. The $L$ axis runs from top to bottom. The maximum for $L$ is 100 , which represents white, while the minimum for $L$ is zero, which represents black. The $a$ and $b$ axes have no specific numerical limits; positive $a$ is red, negative $a$ is green, positive $b$ is yellow, and negative $b$ is blue (Sehlstedt-Persson 2005). The total color change of all the treated paper samples was expressed as $\Delta \mathrm{E}$, which was calculated according to Eq. 1,

$$
\Delta E=\sqrt{(\Delta L)^{2}+(\Delta a)^{2}+(\Delta b)^{2}}
$$

where $(\Delta L)^{2},(\Delta a)^{2}$, and $(\Delta b)^{2}$ are the differences between the values of the respective color indices before and after treatment.

\section{Fourier Transform Infrared (FTIR) Analysis}

Fourier transform infrared analysis was used to monitor the chemical composition and changes that occurred in the paper due to treatment. The samples were analyzed with an FTIR spectrometer (Model 6100, Jasco, Tokyo, Japan). The spectra were obtained in transmission mode with a triglycine sulfate (TGS) detector via the $\mathrm{KBr}$ method and represent $2 \mathrm{~mm} / \mathrm{s}$ co-added scans in the spectral region from 4000 to $400 \mathrm{~cm}^{-1}$, with a resolution of $4 \mathrm{~cm}^{-1}$ (Salim et al. 2020).

\section{Water Absorption}

The samples were cut into $3 \mathrm{~cm} \times 3 \mathrm{~cm}$ pieces (Fig. 3 ), and then the dry weight of the sample was recorded. After that, the pieces were placed in Petri dishes and $12 \mathrm{~mL}$ of distilled water was added (at a temperature of $23{ }^{\circ} \mathrm{C} \pm 1{ }^{\circ} \mathrm{C}\left(73.4^{\circ} \mathrm{F}\right)$ ) and left for $120 \mathrm{sec}$. Afterwards its wet weight was recorded, according to TAPPI standard T441 om-09 (2013). The water absorption was estimated by using three samples from the same concentration, and the average was calculated and according to Eq. 2,

$$
\text { Water Absorption (\%) }=\frac{W W-W D}{W D} \times 100
$$

where WW is the wet weight $(\mathrm{g})$, and WD is the dry weight $(\mathrm{g})$.

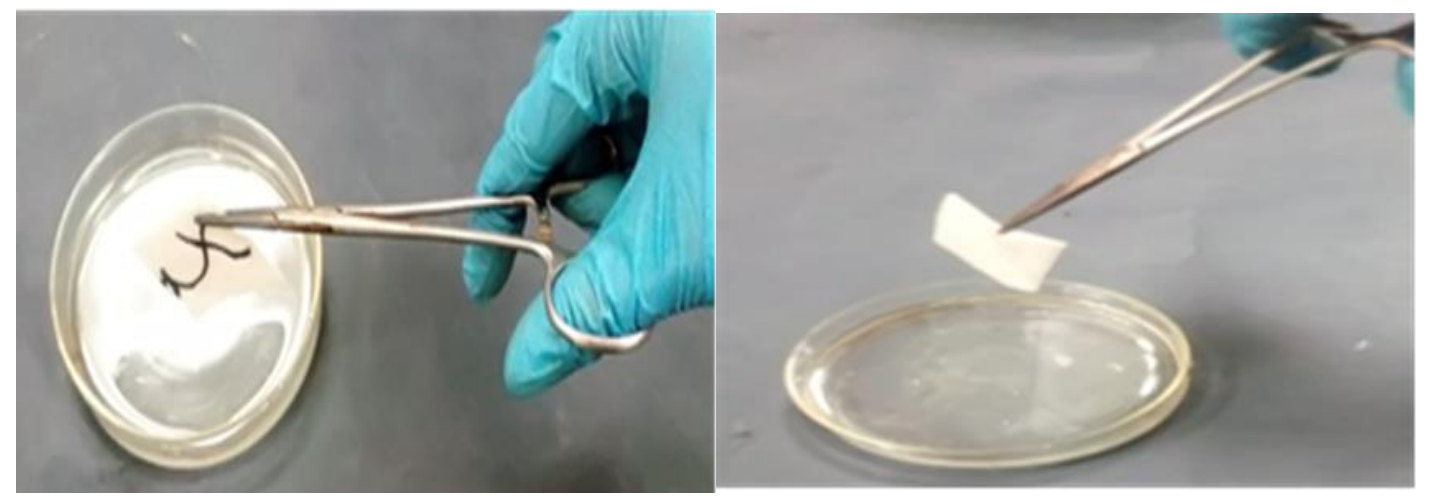

Fig. 3. Preparing the samples and immersing them in distilled water before weighing 


\section{Statistical Analysis}

The water absorption data was statistically measured using one-way ANOVA, and the comparison among means was performed using LSD at a 0.05 level of probability (SAS 2001).

\section{RESULTS AND DISCUSSION}

\section{Universal Serial Bus (USB) Digital Microscope}

At first, no visual changes were detected by eye, but when comparing the standard samples before and after the ageing process USB Digital Microscope, it was found that the pores in the paper were larger after undergoing artificial ageing. In addition, it was found that the paper used was poorly manufactured due to the appearance of stains and dirt (Fig. 4).
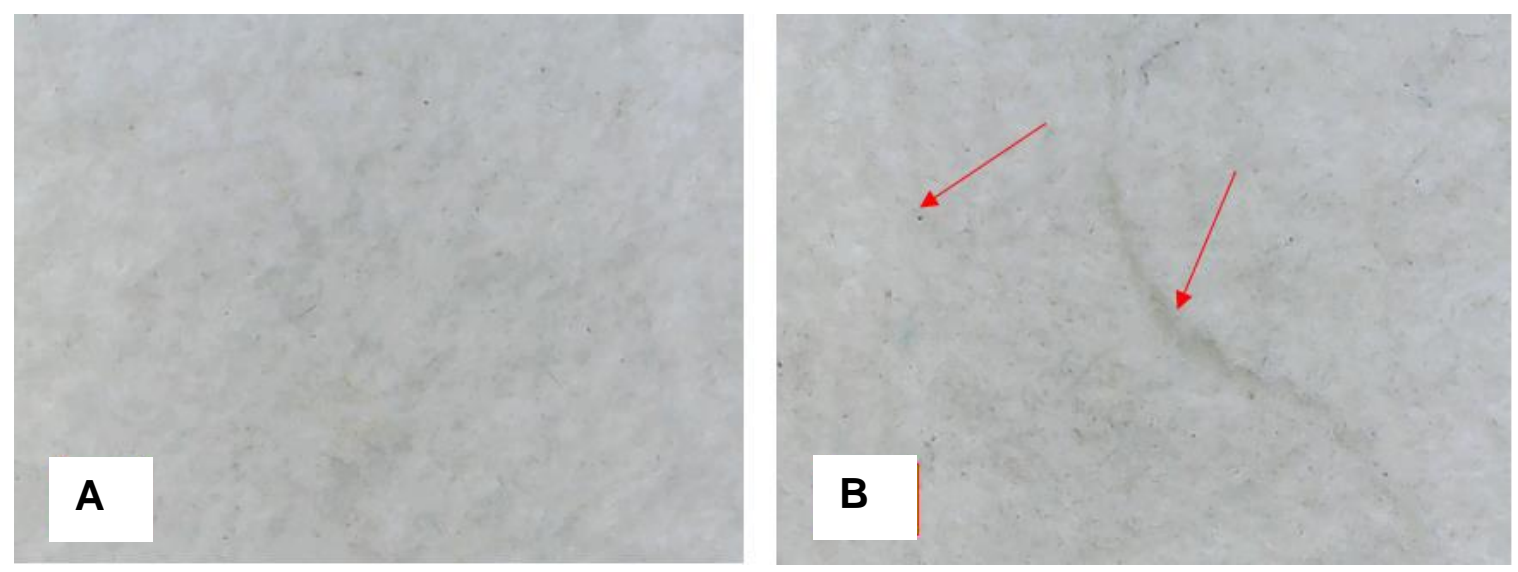

Fig. 4. Surface of standard sample by USB microscope before and after ageing: (A) before; (B) after

Using the treated materials at different concentrations, it was found that frankincense and rice starch gave best results at three concentrations $\left(\mathrm{F}_{1.5} \mathrm{~S}_{0.5}, \mathrm{~F}_{0.5} \mathrm{~S}_{1.5}\right.$, and $\mathrm{F}_{2} \mathrm{~S}_{1}$ ). It was apparent by the naked eye that the increase in frankincense concentration after treatment gave the surface of the paper an unwanted shine. In addition, it was found that by increasing the rice starch concentration, the surface became slightly whiter, as shown in Fig. 5. After performing the microscopy examination, it was found that the three best concentrations were $F_{1.5} S_{0.5}, F_{0.5} S_{1.5}$, and $F_{2} S_{1}$. After the treatment, it was observed that one of the $\mathrm{F}_{1.75} \mathrm{~S}_{0.25}$ samples was accidentally exposed to some drops of distilled water and after seven days, it showed green fungal stains. This hinted at the possibility of the treated material being susceptible to fungal attack (Fig. 6), although some studies mentioned that frankincense oil has antifungal properties (Al-Yasiry and Kiczorowska 2016). Furthermore, it was observed that higher concentration of rice starch compared to frankincense $\left(\mathrm{F}_{0.5} \mathrm{~S}_{1.5}\right)$ made the sample slightly whiter than the standard sample after artificial ageing (Fig. 7). 

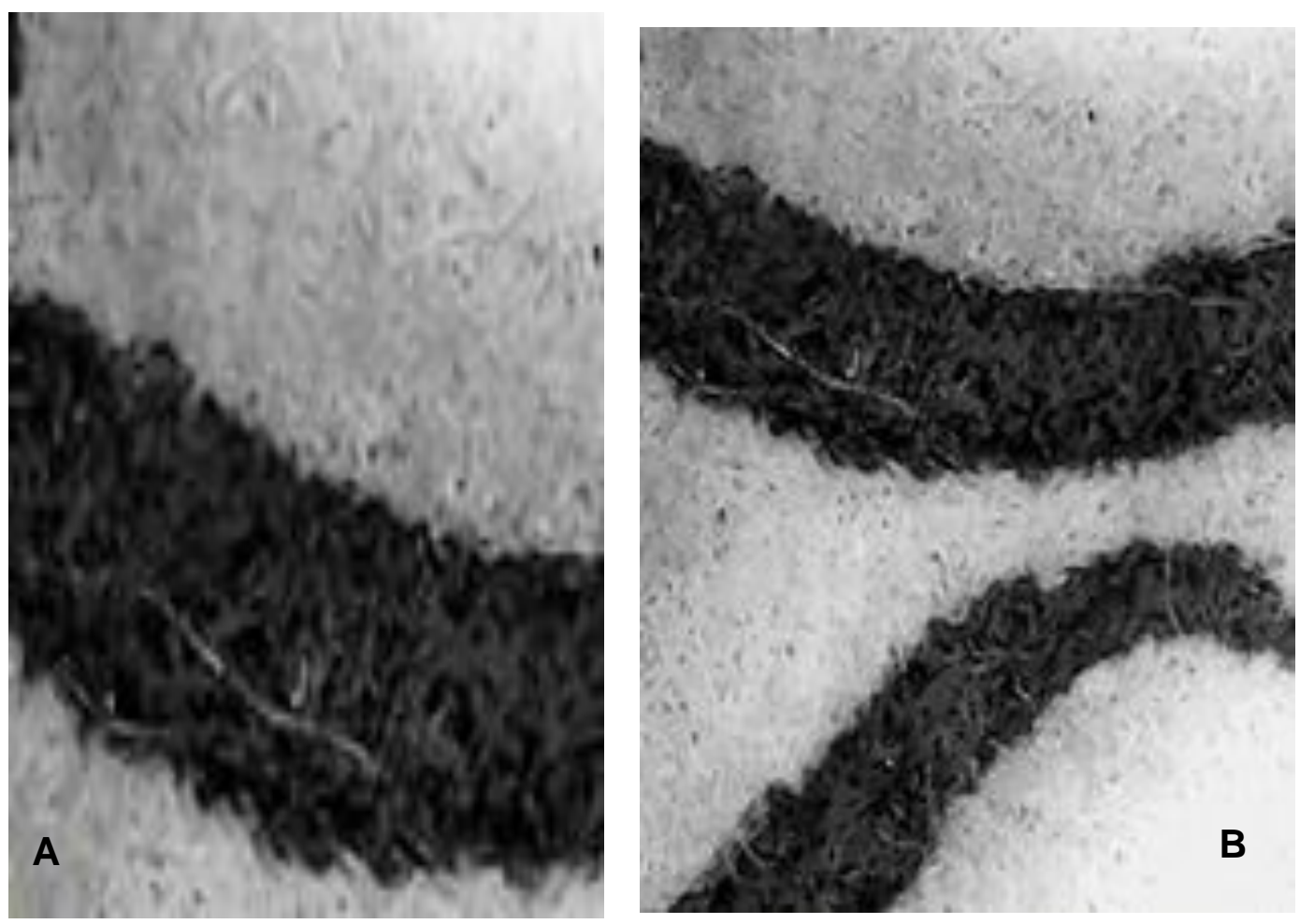

Fig. 5. Images show that with an increase of rice starch concentration, the surface became slightly whiter. Part (A) shows a specimen with low concentration of starch (sample $\mathrm{F}_{1.5} \mathrm{~S}_{0.5}$ ), while (B) shows results with a high concentration of starch (sample $\mathrm{F}_{0.5} \mathrm{~S}_{1.5}$ ).

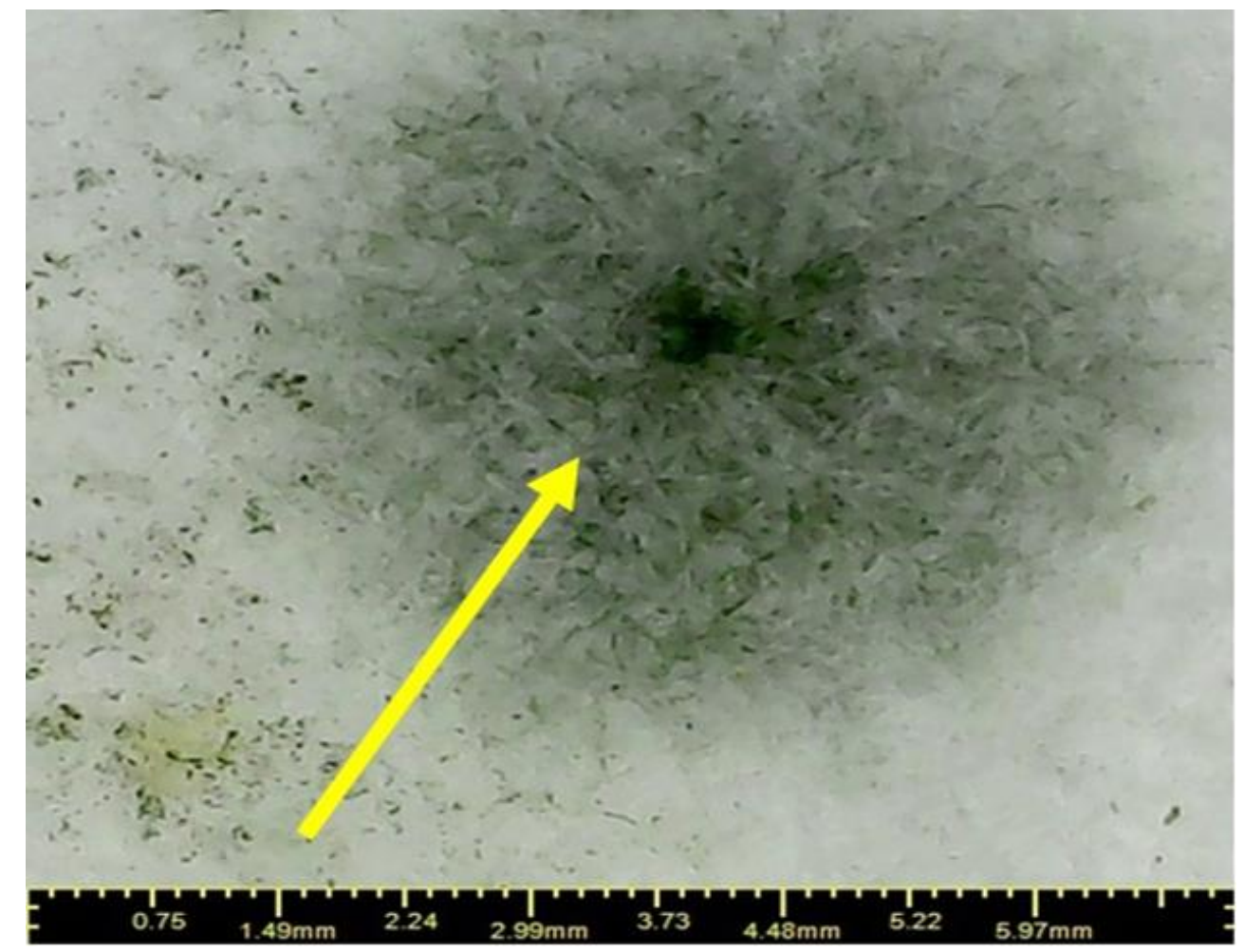

Fig. 6. Fungal stains on sample F1.75S0.25 due to the exposure of the treated material to water 


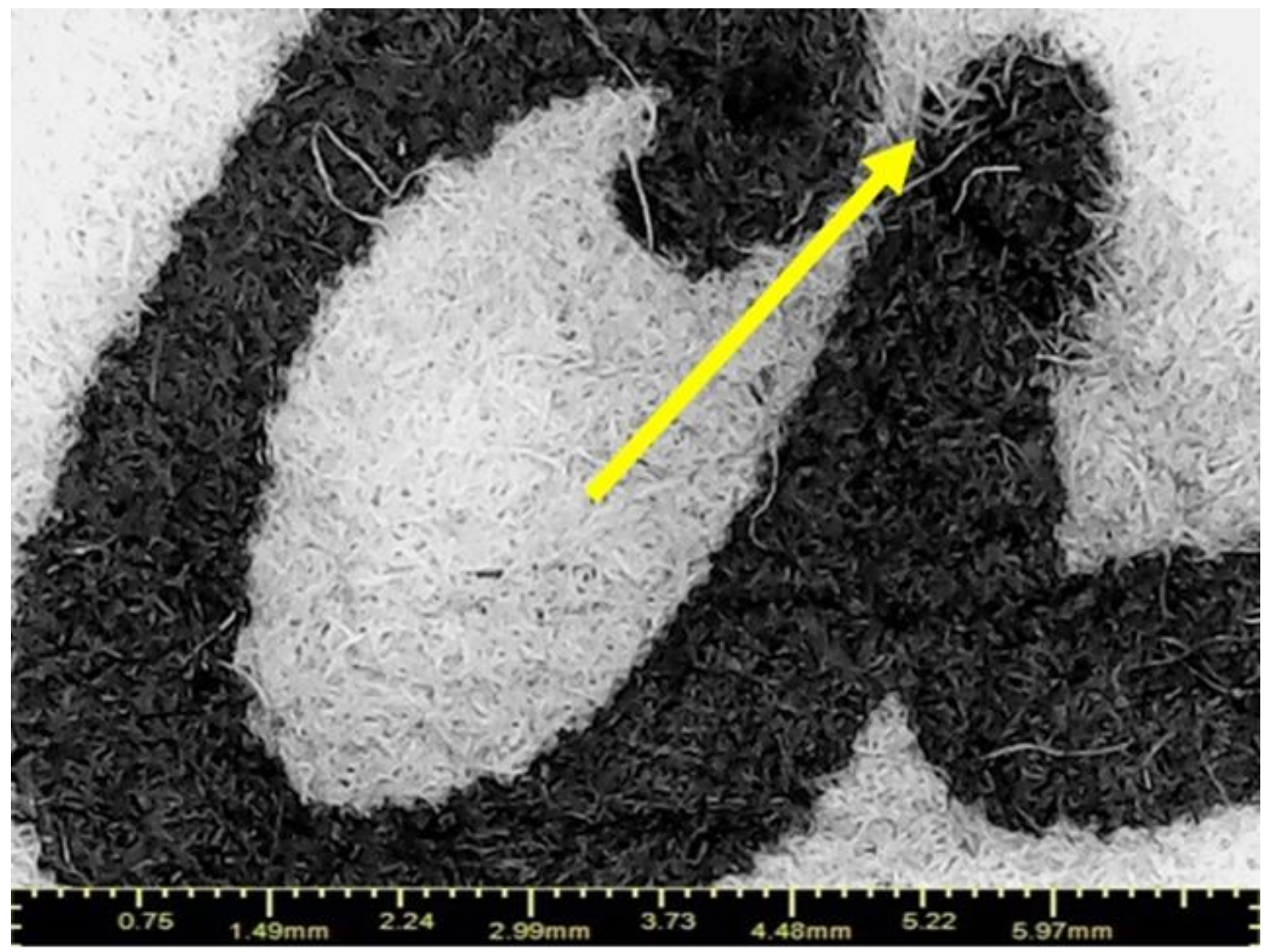

Fig. 7. Fibers curl in the $\mathrm{F}_{0.5} \mathrm{~S}_{1.5}$ sample; the presence of a higher concentration of rice starch compared to frankincense made the sample slightly whiter than the standard sample after artificial ageing

\section{Scanning Electron Microscope}

Scanning electron microscopy was used to detect the shape of the wood fibers, the effect of artificial ageing on the fibers, and the effect of the treatment materials. Figure 8 shows the effect of the artificial ageing process on the wood fibers, i.e., its deterioration in the form of the loss of water content and shrinkage, in addition to the weakness of the fibers and gaps (Zervos 2010). It was also observable that rice starch created connections and bridges of starch molecules between the cellulose bundles. This supported the observation that viscosity of the starch at the time of application was suitable for easily penetrating the walls of the wood cells. However, the frankincense treatment led to the formation of crystals that coated the fibers, which were not noticeable in the standard sample (Fig. 9), as they melted due to the heat of the artificial ageing process (Edwards and Falk 1997; Cruz-Cañizares et al. 2005; Shi et al. 2012) (Fig. 10). It was observed that the frankincense particles were completely absorbed by the cell walls (Fig. 10c and 10d) (Amagliani et al. 2016). Therefore, frankincense utilizes its full strength in supporting the wood fibers with exposure to the ageing process, which is a qualitative advantage of frankincense. It can be seen from Fig. 11 that when the concentration of frankincense to starch was increased to $1.5 \%$, the bonding between the fiber bundles was strong and a clear improvement appeared in the structure of the paper, as the thickness of the fibers increased. 


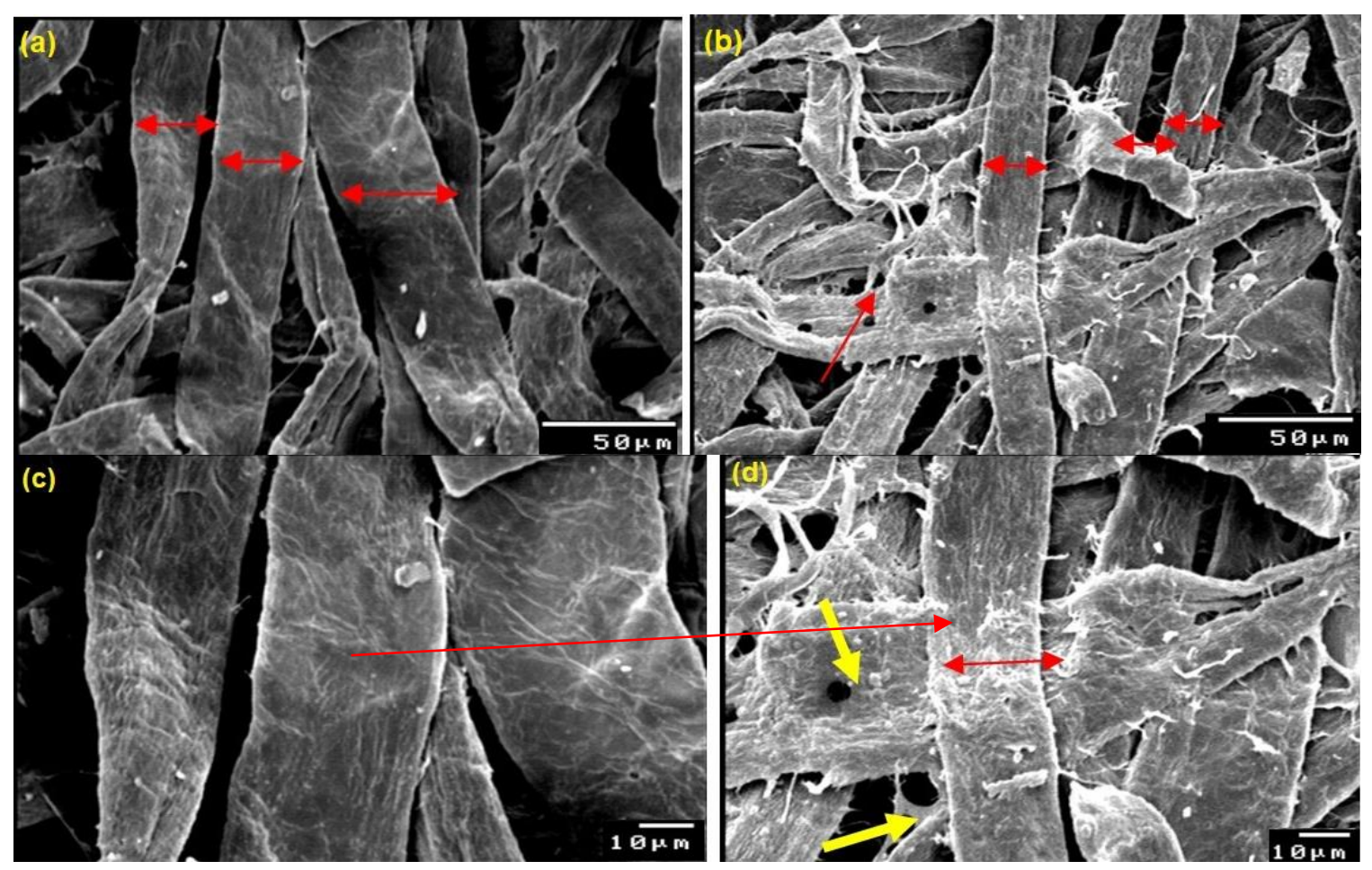

Fig. 8. Deterioration of the wood fibers due to artificial ageing in the form of shrinkage and fragility in wood fiber ( $b$ and $d$ ) in comparison to a standard sample before artificial ageing ( $a$ and $c$ ). By comparing the images $\mathrm{c}$ and $\mathrm{d}$, a clear shrinkage in the fibers was apparent, as shown by the big red arrows.
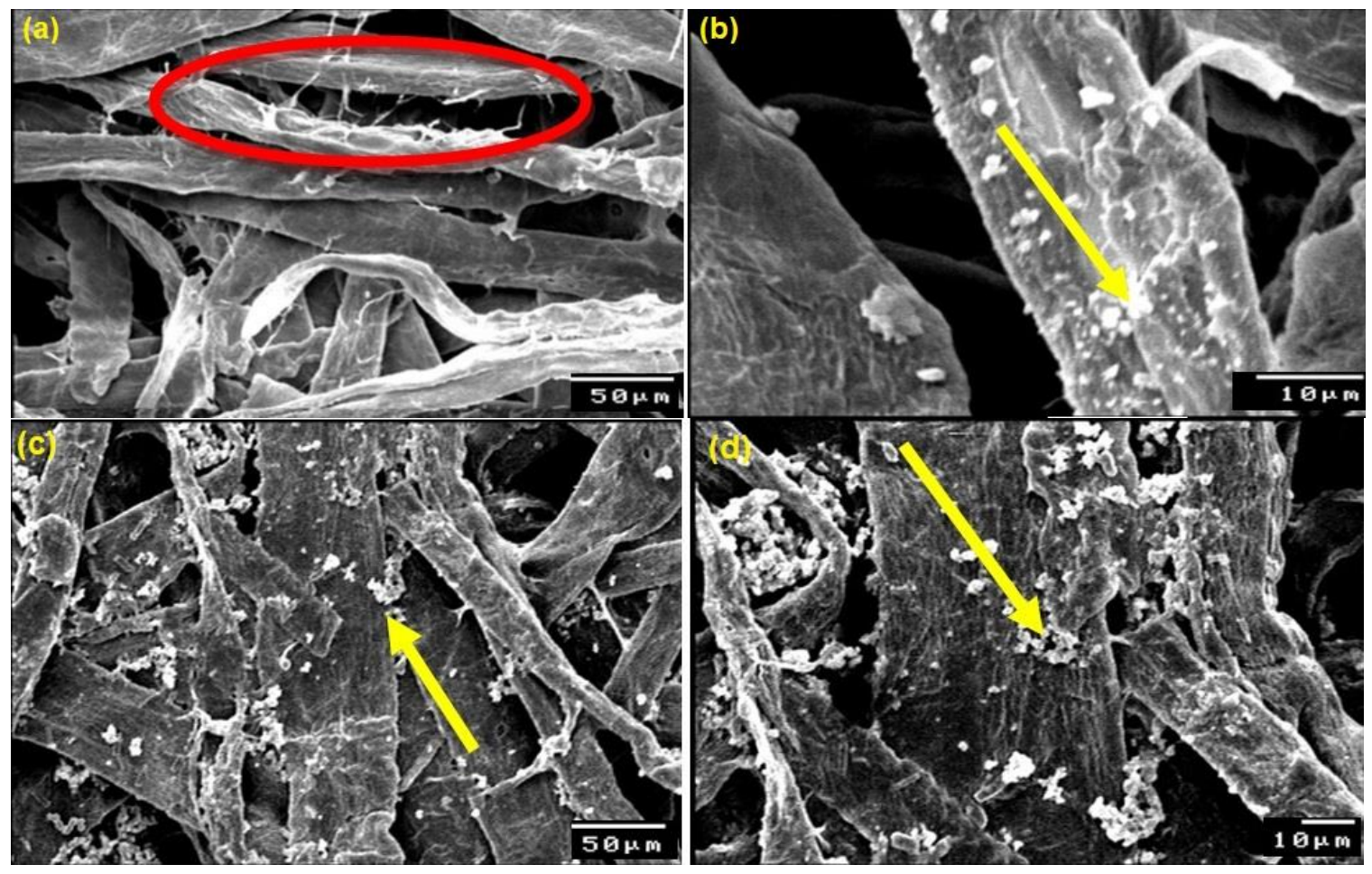

Fig. 9. The size of fiber fibrils increased after treatment by rice starch, which resulted in more linking between fibers (a); and the small frankincense crystals in sample $\mathrm{F}_{1.75} \mathrm{~S}_{0.25}$ that appeared after the ageing process (b, $c$, and d). 

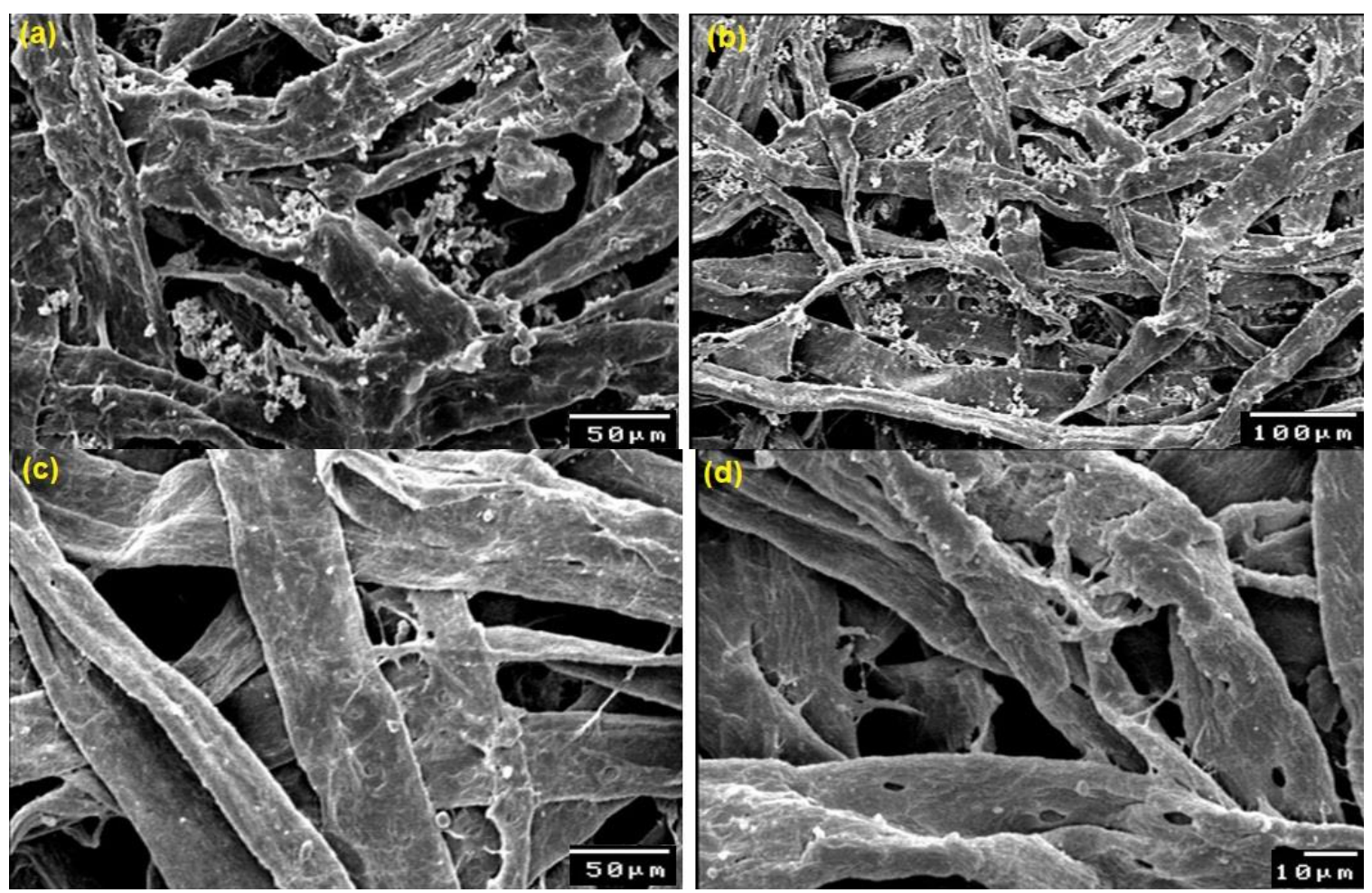

Fig. 10. Frankincense crystals in sample $\mathrm{F}_{1.5} \mathrm{~S} 0.5$ that appeared before the ageing process (a and $b$ ) but disappeared after the ageing process ( $c$ and $d$ )
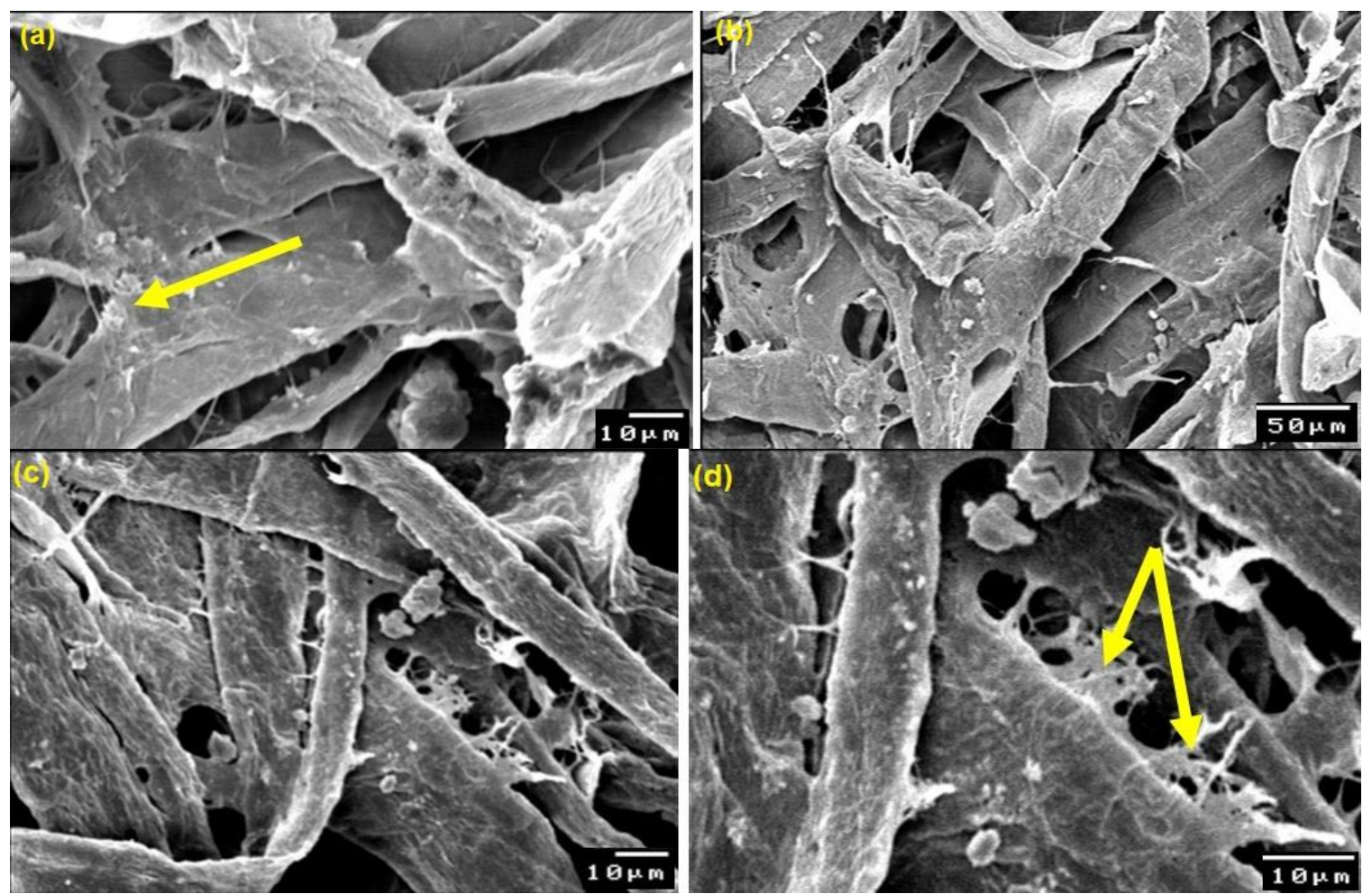

Fig. 11. Bridges between the wood fibers that appeared in sample $F_{0.5} S_{1.5}$ after the artificial ageing process 


\section{pH Measurement}

Under accelerated ageing of cellulose, the main chemical pathways for cellulose degradation are hydrolysis and oxidation. In the hydrolysis process, the water in cellulose cells spontaneously ionizes into $\mathrm{H}_{3} \mathrm{O}^{+}$and hydroxyl groups $\left(\mathrm{OH}^{-}\right)$(Hassan 2016; Speight 2018; Noshy et al. 2021). In the presence of dust particles (basic salt), free radicals in salt such sodium or copper react very little with the hydroxide ions $(\mathrm{OH}-)$, whereas hydronium ions combine with the acetate ions to produce acetic acid $\left(\mathrm{CH}_{3} \mathrm{COOH}\right)$, which reduces the $\mathrm{pH}$ of cellulose fibers. It should be noted that when preparing the samples for $\mathrm{pH}$ measurement, a white layer deposited around the ink surface was observed (Fig. 12) in sample $\mathrm{F}_{0.5} \mathrm{~S}_{1.5}$ (which had a high concentration of frankincense). This showed that when the treated samples with a high concentration of frankincense were exposed to water, it caused whiteness to appear around the ink, which is an advantage in the process of displaying opaque inks in a safe way. From the $\mathrm{pH}$ measurement results (Table 2), it was found that there were no considerable changes before and after treatment.

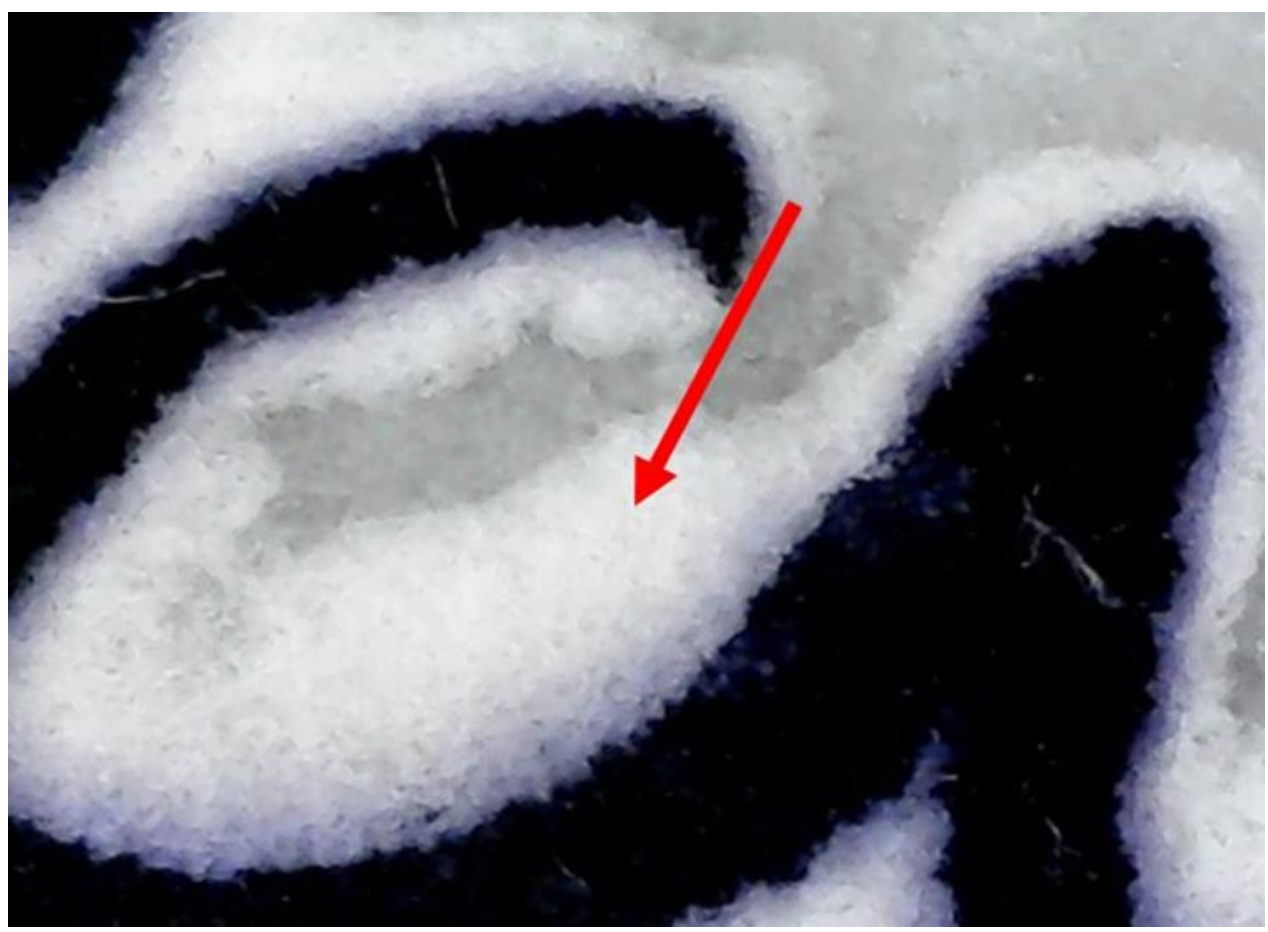

Fig. 12. A digital microscope image of the $\mathrm{F}_{0.5} \mathrm{~S}_{1.5}$ sample after cold extraction shows a white layer deposition around the ink surface

Table 2. Results of the $\mathrm{pH}$ Meter at Different Treatment Concentrations Before and After the Ageing Process

\begin{tabular}{|c|c|c|}
\hline \multirow{2}{*}{ Sample } & \multicolumn{2}{|c|}{$\mathrm{pH}$ After Cold Extraction } \\
\cline { 2 - 3 } & Before Ageing & After Ageing \\
\hline Standard & 6.5 & 6.2 \\
\hline $\mathrm{F}_{1.5} \mathrm{~S}_{0.5}$ & 6.4 & 6.2 \\
\hline $\mathrm{F}_{2} \mathrm{~S}_{1}$ & 6.6 & 6.3 \\
\hline $\mathrm{F}_{0.5} \mathrm{~S}_{1.5}$ & 6.4 & 6.4 \\
\hline $\mathrm{F}_{1.75} \mathrm{~S}_{0.25}$ & 6.4 & 6.3 \\
\hline
\end{tabular}




\section{Fourier Transform Infrared (FTIR) Analysis}

Figure 13a shows the FTIR spectra of the standard samples before and after the artificial ageing process. It was found that there was not an observable change in the $\mathrm{OH}$ region of all the samples. Furthermore, after the ageing process, new bands appeared at $900.6,910.3$, and $952.5 \mathrm{~cm}^{-1}$ (in comparison to the unaged sample). This may be due to the formation of an ester (C-O) group as well as $\mathrm{C}-\mathrm{OH}$ stretching resulting from the decomposition of the pyranose ring. Furthermore, multiple carbonyl groups were formed as a result of the oxidation of cellulose molecules found in the $\mathrm{C}-\mathrm{OH}$ groups, where the oxidation process of cellulose can easily occur (Hassan 2021).

From Table 3, a dramatic increase in $\mathrm{OH}$ stretching in all the treated sample was observed, especially in sampleF $\mathrm{S}_{1}$, which supports the role of frankincense in terms of increasing the hydration of the treated sample. In addition, a shift in the $\mathrm{C}=\mathrm{O}$ bond (from 1634 to $1639 \mathrm{~cm}^{-1}$ ) was detected, which explains the role of the frankincense molecules in terms of changing the structure of the carbonyl groups, thus reducing degradation processes even when subjected to accelerated ageing (Table 3). Furthermore, a notable increase in $\mathrm{CH}_{2}$ stretching was observed in the treated samples, even after undergoing the ageing process; the intensity of these peaks remained higher than the control peak (Fig. 12b through 12d). The stretching of the $\mathrm{C}-\mathrm{H}$ band, which is evidence of complete water desorption, can increase and improve the crystalline of paper (Hassan 2015; Mansour et al. 2021a). In addition, it was observed that the absorption bands located at 1428, 1367, 1334, 1027 , and $896 \mathrm{~cm}^{-1}$ belong to the stretching and bending vibrations of the $-\mathrm{CH}_{2},-\mathrm{CH},-\mathrm{OH}$, and $\mathrm{C}-\mathrm{O}$ bonds in cellulose and were increased, especially in the treated sample $\mathrm{F}_{1.5} \mathrm{~S}_{0.5}$ (Fig. 12b).

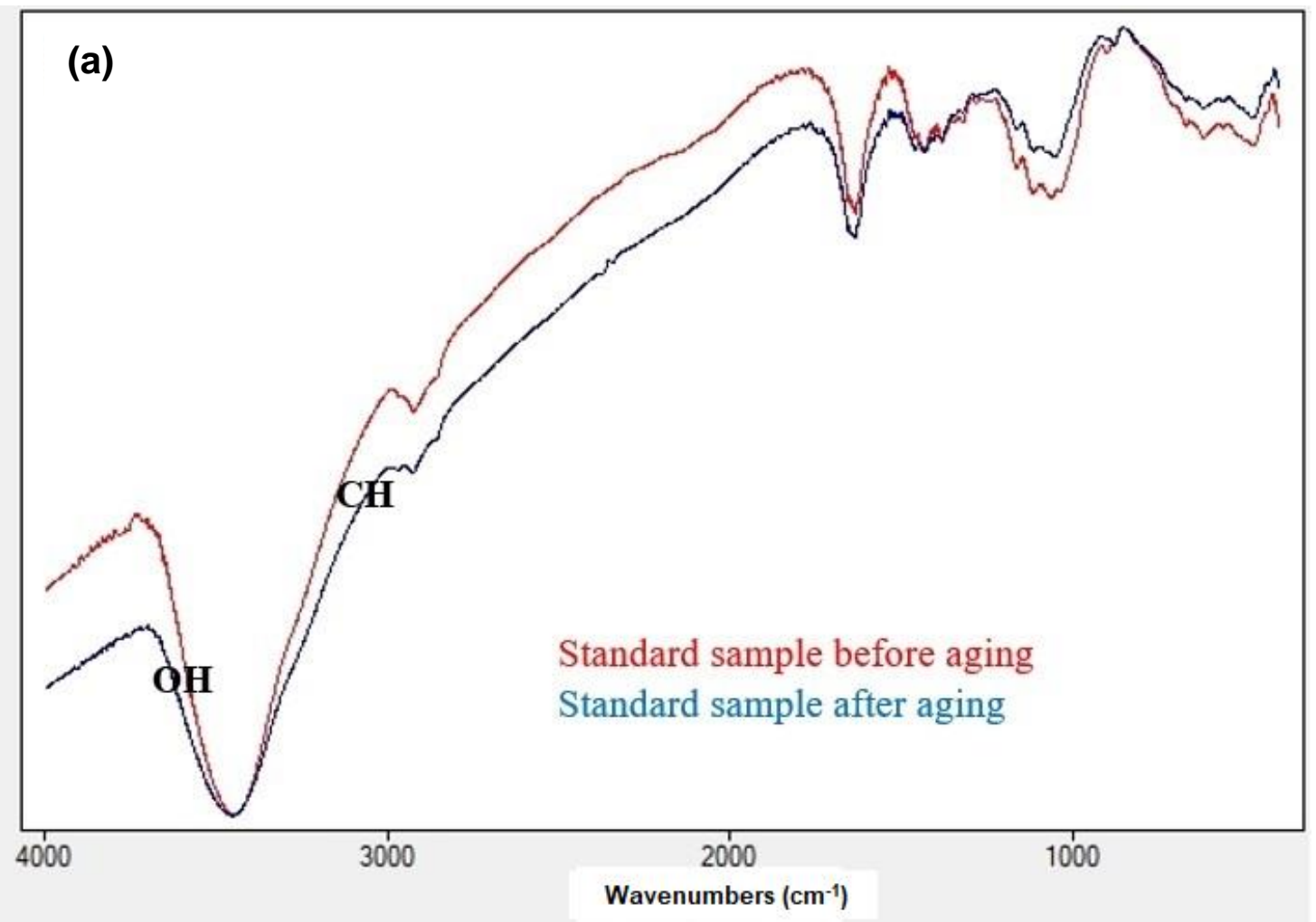



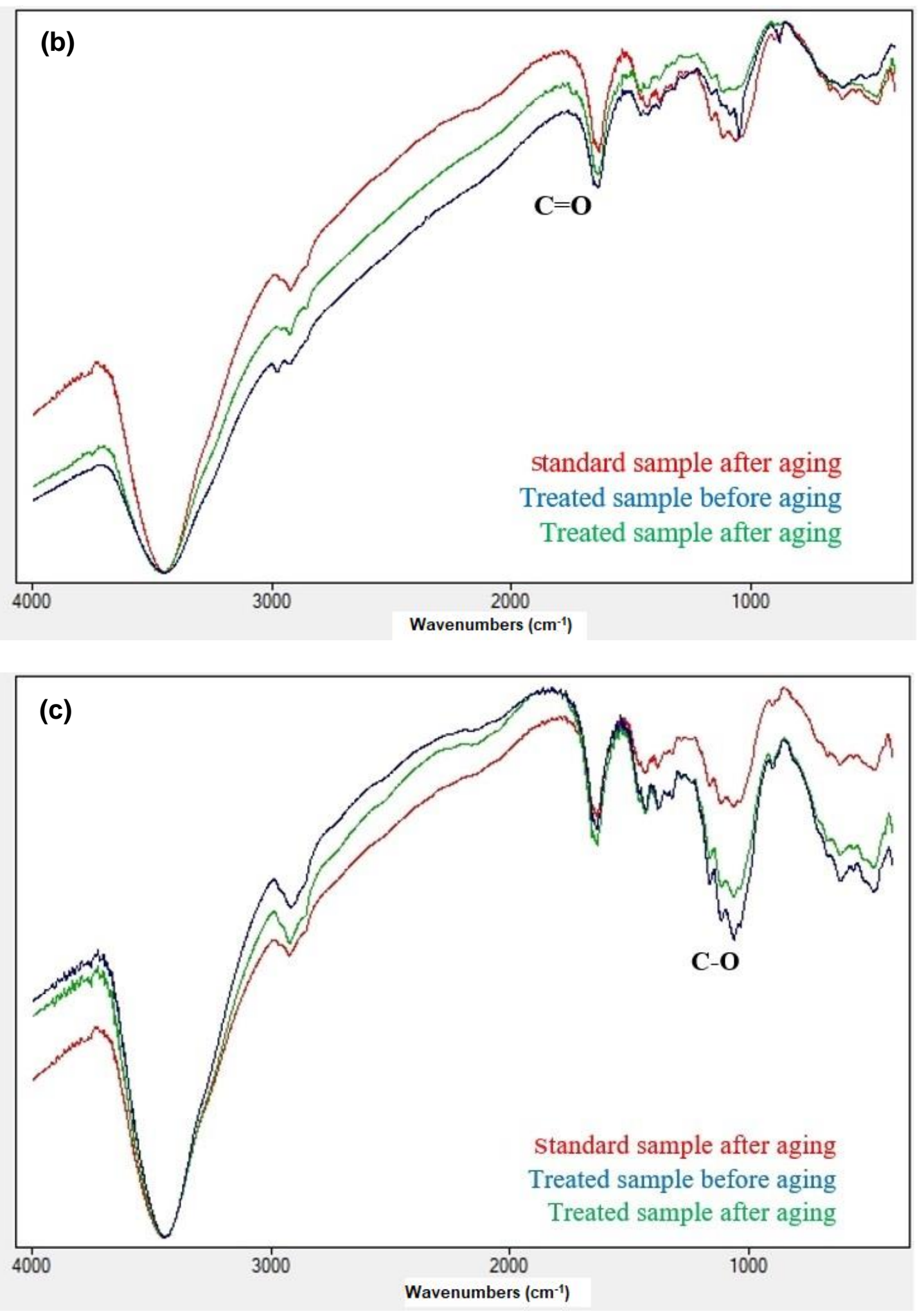

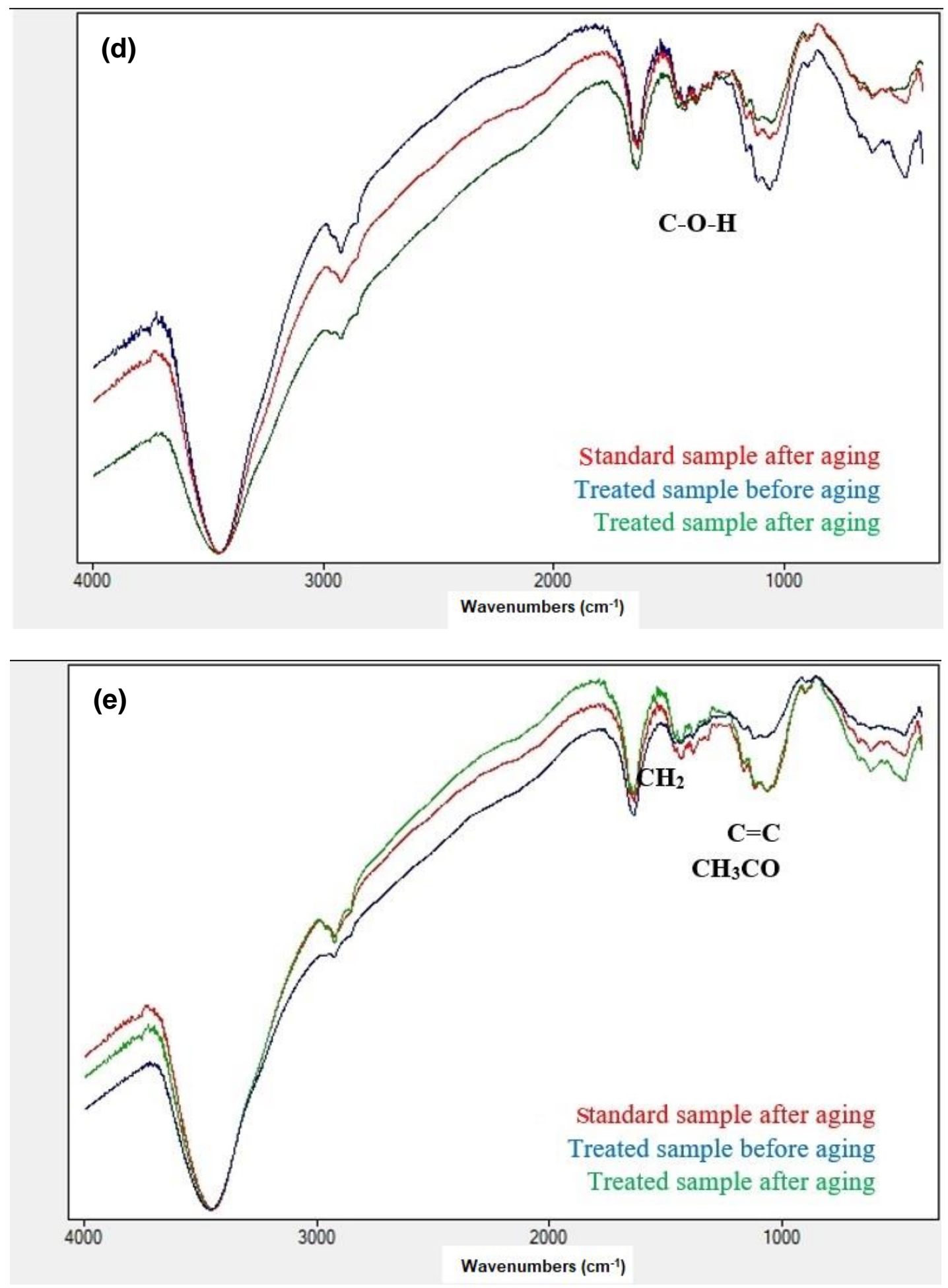

Fig. 13. (a) FTIR spectra of the standard samples before and after the artificial ageing processes; (b) a comparison between the standard sample and the treated sample $\mathrm{F}_{1.5} \mathrm{~S}_{0.5}$, where an obvious improvement can be seen in the treated sample by the increase in the intensity of the bending vibrations of $-\mathrm{CH}_{2}$ and $-\mathrm{CH},-\mathrm{OH}$, and $\mathrm{C}-\mathrm{O}$ bonds and decrease of $\mathrm{C}=\mathrm{O}$; (c) a comparison between the standard sample and the treated sample $\mathrm{F}_{0.5} \mathrm{~S}_{1.5}$, which shows an decrease in the $\mathrm{OH}$ group; (d) a comparison between the standard sample and the treated sample $\mathrm{F}_{1.75} \mathrm{~S}_{0.25}$, which shows an increase in the $\mathrm{CH}_{2}$ peak; and (e) a comparison between the standard sample and treated sample $\mathrm{F}_{2} \mathrm{~S}_{1}$, which shows an increase in the peak of the $\mathrm{C}=\mathrm{O}$ group. 
It should be noted that there was a slight shift in $\mathrm{OH}$ stretching in treated sample $\mathrm{F}_{0.5} \mathrm{~S}_{1.5}$. (Fig. 13c), where the $\mathrm{OH}$ stretching shifted from 3452 to $3443 \mathrm{~cm}^{-1}$. This shift could be due to the effect of the temperature on the paper and starch, which caused a loss in water content of the samples.

From Fig. 13d, which shows the peaks diagram of the $\mathrm{F}_{1.75} \mathrm{~S}_{0.25}$ sample, it was concluded that with an increase in concentration of frankincense in the mixture, the intensities of the topical variations of cellulose also dramatically increased. In addition, the variations responsible for the crystalline regions in cellulose (the bands at approximately 1420,1330 , and $1430 \mathrm{~cm}^{-1}$ ) especially increased. This was due to the oils in the chemical composition of frankincense; for treated sample $\mathrm{F}_{2} \mathrm{~S}_{1}$ there was an increase in the bands at approximately 1420 and $1430 \mathrm{~cm}^{-1}$ associated with the amount of the crystalline structure of the cellulose, as shown in Fig. 13e (Al-Harrasi et al. 2018). From FTIR results, it was confirmed that the $\mathrm{F}_{2} \mathrm{~S}_{1}$ and $\mathrm{F}_{1.75} \mathrm{~S}_{0.25}$ samples were the best concentrations for resizing paper.

Table 3. Changes in Functional Groups of the Treated Samples

\begin{tabular}{|c|c|c|c|c|c|c|c|c|}
\hline \multirow{2}{*}{\multicolumn{2}{|c|}{ Sample }} & \multicolumn{7}{|c|}{ Functional Groups $\left(\mathrm{cm}^{-1}\right)$} \\
\hline & & $\mathrm{OH}^{*}$ & $\mathrm{C}-\mathrm{H}$ * & $\begin{array}{c}\mathrm{C}=\mathrm{O} \text { ester } \\
\text { carbonyl }\end{array}$ & $\mathrm{CH}_{2}{ }^{* *}$ & $\begin{array}{c}\mathrm{C}=\mathrm{C} \text { and } \\
\mathrm{CH}_{3} \mathrm{CO} \\
\text { (frankincense) }\end{array}$ & $\mathrm{C}-\mathrm{O}-\mathrm{H}^{* *}$ & $\begin{array}{c}\text { C-O } \\
\text { stretching } \\
\text { band }\end{array}$ \\
\hline Standa & & 3452 & 2921 & 1634 & 1322 & 1427 & 1163 & 1056 \\
\hline $\mathrm{F}_{1.5} \mathrm{~S}_{.5}$ & $B$ & 3451 & 2930 & 1635 & 1327 & 1433 & 1163 & 1049 \\
\hline $\mathrm{F}_{1.5} \mathrm{~S}_{.5}$ & $A$ & 3449 & 2927 & 1638 & 1330 & 1440 & 1160 & 1052 \\
\hline $\mathrm{F}_{2} \mathrm{~S}_{1}$ & $\mathrm{~B}$ & 3452 & 2927 & 1636 & 1324 & 1439 & 1154 & 1066 \\
\hline $\mathrm{F}_{2} \mathrm{~S}_{1}$ & $A$ & 3455 & 2930 & 1639 & 1327 & 1442 & 1148 & 1069 \\
\hline $\mathrm{F}_{1.75} \mathrm{~S}_{.25}$ & $\mathrm{~B}$ & 3451 & 2930 & 1636 & 1327 & 1433 & 1163 & 1062 \\
\hline$F_{1.75} S_{.25}$ & A & 3452 & 2933 & 1639 & 1330 & 1436 & 1160 & 1057 \\
\hline $\mathrm{F}_{.5} \mathrm{~S}_{1.5}$ & $B$ & 3449 & 2921 & 1633 & 1322 & 1430 & 1160 & 1060 \\
\hline $\mathrm{F}_{.5} \mathrm{~S}_{1.5}$ & A & 3443 & 2924 & 1636 & 1324 & 1433 & 1163 & 1063 \\
\hline
\end{tabular}

\section{Color Change in the CIELAB System}

Colorimetric testing was used to investigate the color changes induced by the treatment of the paper samples, both by the resizing products and the artificial accelerated ageing tests. Based on the color parameter measurements, the $\Delta E$ values were calculated. The $\Delta E$ scale in organic material conservation is shown in Table 4 (Darwish 2013).

Table 4. Relationship between $\Delta E$ and the Qualitative Degree of Color Change

\begin{tabular}{|c|c|}
\hline Very small difference & $\Delta E<0.5$ \\
\hline Small difference & $\Delta E<2$ \\
\hline Fairly perceptible difference & $\Delta E<3$ \\
\hline Perceptible difference & $\Delta E<6$ \\
\hline Strong difference & $\Delta E<12$ \\
\hline Different colors & $\Delta E>12$ \\
\hline
\end{tabular}

It was also previously mentioned that starch and frankincense were used in resizing the paper samples at different concentrations, and the paper was subjected to artificial ageing using moisture and heat. Therefore, it was clear from the results of the color change values when comparing the standard sample before and after artificial ageing that the color 
change value was 0.7 . The ageing process caused a small difference in color change in the paper samples that were manufactured from wood pulp (Table 5). In addition, when comparing the samples treated with frankincense and starch before artificial ageing with the standard sample, it was observed that the lowest samples in terms of color change values was the treated sample $\mathrm{F}_{1.75} \mathrm{~S}_{0.25}$, with a $\Delta E$ value of 0.8 .

The $\Delta E$ value for the treated sample $\mathrm{F}_{2} \mathrm{~S}_{1}$ before undergoing the ageing process was 0.9 , while the treated samples $\mathrm{F}_{0.5} \mathrm{~S}_{1.5}$ and $\mathrm{F}_{1.5} \mathrm{~S}_{0.5}$ had $\Delta E$ values before undergoing the ageing process of 1.5. After exposing the treated samples to the ageing process, it was found that the $\Delta E$ value increased in all samples, while the sample that had the least color change was treated sample $\mathrm{F}_{1.75} \mathrm{~S}_{0.25}$, where an increase of 0.9 occurred. The value of the color change was 1.7, and the sample that had the greatest increase in color change was the treated sample $\mathrm{F}_{1.5} \mathrm{~S}_{0.5}$, which had an increase of $3.1^{\circ}$, resulting in a $\Delta E$ of 4 . The color change that occurred in the samples can be attributed to the chemical changes in the samples as a result of the treatment with starch and frankincense. These chemical changes were identified through FTIR analysis, which showed the occurrence of oxidation and hydrolysis in the samples, involving a dramatic increase in the carbonyl groups $(\mathrm{C}=\mathrm{O})$. Therefore, it was evident through FTIR analysis that with an increase in the percentage of frankincense, the values of the color change also increased, and all the values of the color change in the samples after the ageing process were less than 4.5. This indicated that all the treatment concentrations were within the permissible limits, but it is preferable to use the lowest concentrations because no noticeable color change occurred (Table 5).

Table 5. $\Delta E$ Measurements for Treated Samples with Different Concentrations

\begin{tabular}{|c|c|c|c|c|}
\hline Name of Samples & $L$ & $a$ & $B$ & $\Delta E$ \\
\hline Standard before ageing & 89.4 & 0.4 & 5.7 & - \\
\hline Standard after ageing & 88.9 & 0.3 & 6.1 & 0.7 \\
\hline $\mathrm{F}_{1.5} \mathrm{~S}_{0.5}$ before ageing & 88.2 & 0.3 & 6.5 & 1.5 \\
\hline $\mathrm{F}_{1.5} \mathrm{~S}_{0.5}$ after ageing & 84.3 & 0.4 & 6.6 & 4.6 \\
\hline $\mathrm{F}_{2} \mathrm{~S}_{1}$ before ageing & 88.6 & 0.3 & 6.9 & 0.9 \\
\hline $\mathrm{F}_{2} \mathrm{~S}_{1}$ after ageing & 88.4 & 0.3 & 7.7 & 2.3 \\
\hline $\mathrm{F}_{1.75} \mathrm{~S}_{0.25}$ before ageing & 88.7 & 0.4 & 6.8 & 0.8 \\
\hline $\mathrm{F}_{1.75} \mathrm{~S}_{0.25}$ after ageing & 88.1 & 0.4 & 6.8 & 1.7 \\
\hline $\mathrm{F}_{0.5} \mathrm{~S}_{1.5}$ before ageing & 88 & 0.4 & 6 & 1.5 \\
\hline $\mathrm{F}_{0.5} \mathrm{~S}_{1.5}$ after ageing & 85.1 & 0.9 & 4.9 & 4 \\
\hline
\end{tabular}

\section{Water Absorption}

When comparing the results of the standard sample before and after the ageing process, it became clear that there was an increase in water absorption (WA) by $26 \%$ in the aged sample, reaching $621 \%$ after ageing compared to the $595 \%$ before ageing. This was because the thermal ageing process resulted in the breaking of the crystallized areas in the paper and thus these areas increased the WA of the paper samples, leading to dryness of the samples. This loss of water content resulted in the increases in WA when the sample was exposed to water again. Zervos (2010) indicated that during thermal ageing, in both humid and dry ovens, the degradation of pure cellulose paper is strictly hydrolytic. Due to this knowledge, when comparing the samples treated before ageing with the standard sample, it became clear that when the concentration of frankincense was $2 \%, 1.75 \%, 1 \%$, and $0.5 \%$, it was found that the frankincense in the sample reduced the WA percentage 
because it is a resin material that is insoluble in water and the chemical composition of frankincense contains oils and acids. Thus, the frankincense covers the fibers and prevents them from absorbing water (Al-Harrasi et al. 2019; Johnson et al. 2019).

In the treated sample $\mathrm{F}_{2} \mathrm{~S}_{1}$, there was an increase in WA by $379.7 \%$, where the WA was $370.3 \%$ in the treated sample. In addition, in the treated sample $\mathrm{F}_{1.75} \mathrm{~S}_{0.25}$, there was an increase in the WA by $379.7 \%$, where the WA rate reached $359.2 \%$ in the treated sample. There was also an increase in the WA in the treated sample $\mathrm{F}_{1.5} \mathrm{~S}_{0.5}$ after ageing by $443.2 \%$, where the WA percentage was $372.2 \%$.

The treated sample $\mathrm{F}_{0.5} \mathrm{~S}_{1.5}$ had a decrease in water absorption of $186 \%$, reaching a percentage of absorption of $409.8 \%$ before ageing, and reached $617.2 \%$ in the aged sample. When comparing the sample that had the highest percentage of frankincense with the sample that had the highest percentage of starch, it was found that the higher the percentage of starch, the greater the WA, due to the occurrence of starch hydrolysis. From these comparisons, it was concluded that the optimal samples were $F_{2} S_{1}$ and $F_{1.75} S_{0.25}$, due to the decrease in WA in these samples because of the increased percentage of frankincense compared to the samples with a high percentage of starch.

Table 6. Degree of Change in Water Absorption for All Treated Samples before and After the Ageing Process

\begin{tabular}{|c|c|c|}
\hline \multirow{2}{*}{ Treatment } & Ageing & Water Absorption (\%) \\
\hline \multirow{2}{*}{ Standard } & $\mathrm{B}$ & $595.32 \pm 50.26 \mathrm{a}^{*}$ \\
\cline { 2 - 3 } & $\mathrm{A}$ & $621.82 \pm 67.60 \mathrm{a}$ \\
\hline \multirow{2}{*}{$\mathrm{F}_{1.5} \mathrm{~S}_{0.5}$} & $\mathrm{~B}$ & $372.22 \pm 63.09 \mathrm{~b}$ \\
\hline \multirow{2}{*}{$\mathrm{F}_{2} \mathrm{~S}_{1}$} & $\mathrm{~A}$ & $443.22 \pm 24.11 \mathrm{~b}$ \\
\cline { 2 - 3 } & $\mathrm{B}$ & $370.28 \pm 34.72 \mathrm{~b}$ \\
\hline \multirow{2}{*}{$\mathrm{F}_{1.75} \mathrm{~S}_{0.25}$} & $\mathrm{~A}$ & $379.72 \pm 58.21 \mathrm{~b}$ \\
\hline \multirow{2}{*}{$\mathrm{F}_{0.5} \mathrm{~S}_{1.5}$} & $\mathrm{~B}$ & $359.17 \pm 85.70 \mathrm{~b}$ \\
\hline \multirow{2}{*}{$\mathrm{LSD}$} & $\mathrm{A}$ & $406.25 \pm 78.31 \mathrm{~b}$ \\
\cline { 2 - 3 } & $\mathrm{B}$ & $409.83 \pm 66.55 \mathrm{~b}$ \\
\hline
\end{tabular}

Note: $\mathrm{B}=$ before ageing; $\mathrm{A}=$ after ageing; * denotes the same letter $(\mathrm{A}-\mathrm{B})$ are not significantly different according to LSD at a 0.05 level of probability

\section{CONCLUSIONS}

1. The two substances, frankincense and rice starch, were able to achieve the objective of this study, which was to reduce the percentage of water absorption and make the paper less susceptible to damage. However, this reduction occurred in varying proportions according to their respective concentrations. The best concentrations were found in samples $\mathrm{F}_{1.75} \mathrm{~S}_{0.25}$ and $\mathrm{F}_{2} \mathrm{~S}_{1}$.

2. The results of the $\mathrm{pH}$ measurement demonstrated that there were no noticeable changes in the $\mathrm{pH}$ values, but the treatments had an effective role in raising the $\mathrm{pH}$ values after the accelerated ageing process compared to the untreated samples. Therefore, these treatments are considered safe for both ancient and modern papers. 
3. It should be noted that in the case of a high concentration of frankincense, the best results were obtained. However, there was a qualitative advantage in the case of sample $\mathrm{F}_{0.5} \mathrm{~S}_{1.5}$, where the high proportion of starch led to form white a layer around the letters of the writing during exposure to water, which may be a promising method for revealing inks.

4. The results of the digital microscopy analysis showed that there was fungal growth on one of the treated paper samples after being exposed to an environment suitable for microbiological growth. This confirmed the inefficiency of frankincense in protecting the paper from microbiological infection.

5. The water absorption examination results showed a decrease in the water absorption percentage of the treated paper because frankincense coated the fibers. Therefore, in conjunction with the results of the previous experiments, it was concluded that the best concentrations that were applied were in samples $F_{1.75} S_{0.25}$ and $F_{2} S_{1}$.

6. It can be concluded from the FTIR analysis that with an increase in concentration of frankincense, the intensities of topical variations of cellulose also dramatically increased. This was especially true for the variations responsible for the crystalline regions in cellulose, i.e., the bands at approximately 1420,1330 , and $1430 \mathrm{~cm}^{-1}$, which were due to the oils in the chemical composition of frankincense.

7. The results of the color change analysis showed that artificial ageing caused a slight color change in the treated samples. After comparing the standard samples with the samples treated with frankincense and starch, it was found that the lowest color change value occurred in treated sample $\mathrm{F}_{1.75} \mathrm{~S}_{0.25}$, which had a $\Delta E$ value of 0.8 . In addition, the most frequently reported samples with an increase were the $\mathrm{F}_{1.5} \mathrm{~S}_{0.5}$ samples, where an increase of $3.1^{\circ}$ occurred; the evidence for this was the occurrence of oxidation, which was identified through FTIR analysis that showed an increase in the carbonyl and hydroxyl groups, which indicated chemical changes. Therefore, it was concluded that increasing the percentage of frankincense increased the rate of color change due to the oils and acids included in its composition, but those changes are within the permissible range.

\section{ACKNOWLEDGMENTS}

This research was funded by the Researchers Supporting Project (No. RSP2021/123) King Saud University, Riyadh, Saudi Arabia.

\section{REFERENCES CITED}

Abo Elgat, W. A. A., Taha, A. S., Böhm, M., Vejmelková, E., Mohamed, W. S., Fares, Y. G. D., and Salem, M. Z. M. (2020). "Evaluation of the mechanical, physical, and anti-fungal properties of flax laboratory papersheets with the nanoparticles treatment," Materials 13(2), 1-23. DOI: 10.3390/ma13020363

Agrawal, O. P., and Barkeshli, M. (1997). Conservation of Books, Manuscripts, and Paper Documents, INTACH, New Delhi, India.

Al-Harrasi, A., Khan, A. L., Asaf, S., and Al-Rawahi, A. (2019). Biology of Genus 
Boswellia, Springer, New York, NY.

Al-Harrasi, A., Rehman, N. U., Khan, A. L., Al-Broumi, M., Al-Amri, I., Hussain, J., Hussain, H., and Csuk, R. (2018). "Chemical, molecular and structural studies of Boswellia species: $\beta$-Boswellic aldehyde and 3-epi-11 $\beta$-dihydroxy BA as precursors in biosynthesis of boswellic acids." PLoS ONE 13 (6), 1-19. DOI:

10.1371/journal.pone.0198666

Al-Harrasi, A., Ali, L., Ceniviva, E., Al-Rawahi, A., Hussain, J., Hussain, H., Rehman, N.U., Abbas, G., and Al-Harrasi, R. (2013). "Antiglycation and antioxidant activities and HPTLC analysis of Boswellia sacra Oleogum resin: The sacred frankincense," Tropical Journal of Pharmaceutical Research 12(4), 597-602.

Ali, N. A. A., Wurster, M., Arnold, N., Teichert, A., Schmidt, J., Lindequist, U., and Wessjohann, L. (2008). "Chemical composition and biological activities of essential oils from the oleogum resins of three endemic SoqotraenBoswellia species," Records of Natural Products 2(1), 6-12.

Al-Yasiry, A. R. M., and Kiczorowska, B. (2016). "Frankincense - Therapeutic properties," Advances in Hygiene \& Experimental Medicine 70, 380-391. DOI: 10.5604/17322693.1200553

Amagliani, L., O’Regan, J., Kelly, A. L., and O’Mahony, J. A. (2016). “Chemistry, structure, functionality and applications of rice starch," Journal of Cereal Science 70, 291-300. DOI: 10.1016/j.jcs.2016.06.014

Ardelean, E., Asandei, D., Tanase, M., and Bobu, E. (2007). "Study on some resizing and consolidation methods of old paper support," European Journal of Science and Theology 3(3), 53-61.

ASTM D778 (1997). "Standard test methods for hydrogen ion concentration ( $\mathrm{pH}$ ) of paper extracts (hot-extraction and cold-extraction procedures)," ASTM International, West Conshohocken, PA.

Bajpai, P. (2018). Biotechnology for Pulp and Paper Processing: Second Edition, Springer Nature, Basingstoke, United Kingdom.

Baker, C. A. (2007). "Sodium carboxymethylcellulose (SCMC) re-evaluated for paper, book, papyrus, and parchment conservation," The Book and Paper Group Annual 26, 177-185.

Bankole, O. M. (2010). "A review of biological deterioration of library materials and possible control strategies in the tropics," Library Review 59(6), 414-429. DOI: $10.1108 / 00242531011053931$

Björdal, C. G. (2012). "Microbial degradation of waterlogged archaeological wood," Journal of Cultural Heritage 13(3S), S118-S122. DOI: 10.1016/j.culher.2012.02.003

Björdal, C. G., Nilsson, T., and Daniel, G. (1999). "Microbial decay of waterlogged archaeological wood found in Sweden applicable to archaeology and conservation," International Biodeterioration \& Biodegradation 43(1), 63-73. DOI: 10.1016/S09648305(98)00070-5

Brown, W. H., and Poon, T. (2016). Introduction to Organic Chemistry, John Wiley \& Sons, Inc., Hoboken, NJ.

Ciolacu, F., Nicu, R., Balan, T., and Bobu, E. (2017). "Chitosan derivatives as bio-based materials for paper heritage conservation," BioResources 12(1), 735-747. DOI: 10.15376/biores.12.1.735-747

Cruz-Cañizares, J. D. 1., Doménech-Carbó, M.-T., Gimeno-Adelantado, J.-V., MateoCastro, R., and Bosch-Reig, F. (2005). "Study of Burseraceae resins used in binding media and varnishes from artworks by gas chromatography-mass spectrometry and 
pyrolysis-gas chromatography-mass spectrometry," Journal of Chromatography A 1093(1-2), 177-194. DOI: 10.1016/j.chroma.2005.07.058

Darwish, S. S. (2013). "Evaluation of the effectiveness of some consolidants used for the treatment of the XIX ${ }^{\text {th }}$ century Egyptian cemetery wall painting," International Journal of Conservation Science 4(4), 413-422.

Dillen, J. R., Dillén, S., and Hamza, M. F. (2016). "Pulp and paper: Wood sources," in: Reference Module in Materials Science and Materials Engineering, S. Hashmi (ed.), Elsevier, Amsterdam, Netherlands.

Edwards, H. G. M., and Falk, M. J. (1997). "Fourier-transform Raman spectroscopic study of frankincense and myrrh," Spectrochimica Acta Part A: Molecular and Biomolecular Spectroscopy 53(13), 2393-2401. DOI: 10.1016/S1386-1425(97)00179-0

Egharevba, H. O. (2019). "Chemical properties of starch and its application in the food industry," in: Chemical Properties of Starch, M. Emeje (ed.), IntechOpen Ltd., London, United Kingdom.

El-Nagerabi, S. A. F., Elshafie, A. E., AlKhanjari, S. S., Al-Bahry, S. N., and Elamin, M. R. (2013). "Biological activities of Boswellia sacra extracts on the growth and aflatoxins secretion of two aflatoxigenic species of Aspergillus species," Food Control 34(2), 763-769. DOI: 10.1016/j.foodcont.2013.06.039

Evetts, D. M., Lockwood A., and Indictor, N. (1989). "Evaluation of some impregnating agents for use in paper conservation," Restaurator10(1), 1-15. DOI: 10.1515/rest.1989.10.1.1

Hassan, R. R. A. (2016). "Thermal degrading of paper: The structure changes of fibres," Egyptian Journal of Archaeological and Restoration Studies 6(2), 71-84.

Hassan, R. R. A. (2015). "Analytical study of a manuscript, 'Tafsir Al khazin' - The seventeenth century AD," Current Science International 3(6), 196-207.

Hassan, R. R. A. (2021). "Sodium dodecyl sulfate micro-emulsion as a smart cleaning agent for archeological manuscripts: Surface investigations," The European Physical Journal Plus136(1), 1-18. DOI: 10.1140/epjp/s13360-020-00973-w

Hassan, R. R. A., Ali, M. F., Fahmy, A.-G. A., Ali, H. M., and Salem, M. Z. M. (2020). "Documentation and evaluation of an ancient paper manuscript with leather binding using spectrometric methods," Journal of Chemistry 2020, 1-10. DOI: $10.1155 / 2020 / 6847910$

Hassan, R. R. A., and Mohamed, W. S. (2017). "Effect of methyl methacrylate/hydroxyethyl methacrylate copolymer on optical and mechanical properties and long-term durability of paper under accelerated ageing," International Journal of Conservation Science 8(2), 237-250.

Hassan, R. R. A., Mahmoud, S. M. A., Nessem, M. A., Aty, R. T. A., Ramzy, M. G., Dessoky, E. S., Abdelkhalek, A., and Salem, M. Z. M. (2021).

"Hydroxypropylcellulose loaded with $\mathrm{ZnO}$ nanoparticles for enhancing the mechanical properties of papyrus (Cyperus papyrus L.) strips," BioResources 16(2), 2607-2625. DOI: 10.15376/biores.16.2.2607-2625

Hidalgo, R. J. D., Córdoba, R., Nabais, P., Silva, V., Melo, M. J., Pina, F., Teixeira, N., and Freitas, V. (2018). "New insights into iron-gall inks through the use of historically accurate reconstructions," Heritage Science 6(1), 1-15. DOI: 10.1186/s40494-018-0228-8

Huang, N., Lin, J., Li, S., Deng, Y., Kong, S., Hong, P., Yang, P., Liao, M., and Hu, Z. (2018). "Preparation and evaluation of squid ink polysaccharide-chitosan as a woundhealing sponge," Materials Science and Engineering: C 82, 354-362. DOI: 
10.1016/j.msec.2017.08.068

Hubbe, M. A., and Bowden, C. (2009). "Handmade paper: A review of its history, craft, and science," BioResources 4(4), 1736-1792. DOI: 10.15376/biores.4.4.1736-1792

Hummert, E., Henniges, U., and Potthast, A. (2013). "Fluorescence labeling of gelatin and methylcellulose: Monitoring their penetration behavior into paper," Cellulose 20 (2), 919-931. DOI: 10.1007/s10570-013-9864-z

Hunter, D. (1978). Papermaking: The History and Technique of an Ancient Craft, Dover Publications, Mineola, NY.

Irvine, S. A., Agrawal, A., Lee, B. H., Chua, H. Y., Low, K. Y., Lau, B. C., Machluf, M., and Venkatraman, S. (2015). "Printing cell-laden gelatin constructs by free-form fabrication and enzymatic protein crosslinking," Biomedical Microdevices 17(1), 1-8. DOI: $10.1007 / \mathrm{s} 10544-014-9915-8$

ISO 5630-3 (1996). "Paper and board - Accelerated ageing - Part 3: Moist heat treatment at 80 degrees C and $65 \%$ relative humidity," International Organization for Standardization, Geneva, Switzerland.

Jančovičová, V., Čeppan, M., Havlínová, B., Reháková, M., and Jakubíková, Z. (2007). "Interactions in iron gall inks," Chemical Papers 61(5), 391-397. DOI: 10.2478/s11696-007-0053-0

Johnson, S., DeCarlo, A., Satyal, P., Dosoky, N. S., Sorensen, A., and Setzer, W. N. (2019). "The chemical composition of Boswellia occulta oleogum resin essential oils," Natural Product Communications 14(7), 1-7. DOI: $10.1177 / 1934578 X 19866307$

Kolbe, G. (2004). "Gelatine in historical paper production and as inhibiting agent for iron-gall ink corrosion on paper," Restaurator 25(1), 26-39. DOI: 10.1515/REST.2004.26

Kovács, R. L., Daróczi, L., Barkóczy, P., Baradács, E., Bakonyi, E., Kovács, S., and Erdélyi, Z. (2021). "Water vapor transmission properties of acrylic organic coatings," Journal of Coatings Technology and Research 18(2), 523-534. DOI: 10.1007/s11998020-00421-5

Kumar, S., Prasad, L., Patel, V. K., Kumar, V., Kumar, A., Yadav, A., and Winczek, J. (2021). "Physical and mechanical properties of natural leaf fiber-reinforced epoxy polyester composites," Polymers 13(9), 1-35. DOI: 10.3390/polym13091369

Liu, X., Fatehi, P., Ni, Y., and Xiao, H. (2010). "Using cationic polyvinyl alcohol (CPVA) to improve the strength of wood-free papers containing high-yield pulp (HYP)," Holzforschung 64(5), 563-569. DOI: 10.1515/hf.2010.078

Liu, Z., Fu, T., Hu, C., Shen, D., Macchioni, N., Sozzi, L., Chen, Y., Liu, J., Tian, X., Ge, Q., et al. (2018). "Microbial community analysis and biodeterioration of waterlogged archaeological wood from the Nanhai No. 1 shipwreck during storage," Scientific Reports 8(1), 1-11. DOI: 10.1038/s41598-018-25484-8

Manjunath, L., and Sailaja, R. R. N. (2014). "PMMA-cellulose acetate phthalate nanocomposites reinforced with silane-treated nanoclay," Cellulose 21(3), 17931802. DOI: $10.1007 / \mathrm{s} 10570-014-0190-\mathrm{x}$

Mansour, M. M. A., Abdel-Megeed, A., Nasser, R. A., and Salem, M. Z. M. (2015). "Comparative evaluation of some woody tree methanolic extracts and Paraloid B-72 against phytopathogenic mold fungi Alternaria tenuissima and Fusarium culmorum," BioResources 10(2), 2570-2584. DOI: 10.15376/biores.10.2.2570-2584

Mansour, M. M. A., and Salem, M. Z. M. (2015). "Evaluation of wood treated with some natural extracts and Paraloid B-72 against the fungus Trichoderma harzianum: Wood 
elemental composition, in-vitro and application evidence," International Biodeterioration \& Biodegradation 100, 62-69. DOI: 10.1016/j.ibiod.2015.02.009

Mansour, M. M. A., Hassan, R. R. A., Mahmoud, S. M. A., and Akl, Y. M. (2021a). “An analytical study on the relationship between the fungal degradation and multicomponent nature of paper manuscripts," Pigment \& Resin Technology 50(4), 309318. DOI: 10.1108/PRT-07-2020-0074

Mansour, M. M. A., Salem, M. Z. M., Hassan, R. R. A., Ali, H. M., Farraj, D. A. A., and Elshikh, M. S. (2021b). "Antifungal potential of three natural oils and their effects on the thermogravimetric and chromatic behaviors when applied to historical paper and various commercial paper sheets," BioResources 16(1), 492-514. DOI:

10.15376/biores.16.1.492-514

Mansour, M., Hassan, R., and Salem, M. Z. M. (2017). "Characterization of historical bookbinding leather by FTIR, SEM-EDX and investigation of fungal species isolated from the leather," Egyptian Journal of Archaeological and Restoration Studies 7(1), 1-10. DOI: 10.21608/EJARS.2017.6823

Marc, A., Engasser, J. M., Moll, M., and Flayeux, R. (1983). "A kinetic model of starch hydrolysis by $\alpha$ - and $\beta$-amylase during mashing," Biotechnology and Bioengineering 25(2), 481-496. DOI: 10.1002/bit.260250214

Meesorn, W., Shirole, A., Vanhecke, D., Espinosa, L. M. d., and Weder, C. (2017). “A simple and versatile strategy to improve the mechanical properties of polymer nanocomposites with cellulose nanocrystals," Macromolecules 50(6), 2364-2374. DOI: 10.1021/acs.macromol.6b02629

Missori, M., Righini, M., and Dupont, A.-L. (2006). "Gelatine sizing and discoloration: A comparative study of optical spectra obtained from ancient and artificially aged modern papers," Optics Communications 263(2), 289-294. DOI: 10.1016/j.optcom.2006.02.004

Mohamed, W. A., Mansour, M. M. A., and Salem, M. Z. M. (2019). “Lemna gibba and Eichhornia crassipes extracts: Clean alternatives for deacidification, antioxidation and fungicidal treatment of historical paper," Journal of Cleaner Production 219, 846-855. DOI: 10.1016/j.jclepro.2019.02.097

Moncmanová, A. (2007). Environmental Deterioration of Materials, Wit Press, Ashurst, United Kingdom.

Nasatto, P. L., Pignon, F., Silveira, J. L., Duarte, M. E. R., Noseda, M. D., and Rinaudo, M. (2015). "Methylcellulose, a cellulose derivative with original physical properties and extended applications," Polymers 7(5), 777-803. DOI: 10.3390/polym7050777

Noshy, W., Ali Hassan, R. R., and Mohammed, N. (2021). "Using biopolymers to strengthen the historical printed paper: Mechanical and optical characters," Pigment \& Resin Technology, Vol. ahead-of-print No. ahead-of-print. DOI: 10.1108/PRT-012021-0008

Pataki, A. (2009). "Remoistenable tissue preparation and its practical aspects," Restaurator 30(1-2), 51-69. DOI: 10.1515/rest.004

Rajabian, A., Sadeghnia, H. R., Fanoudi, S., and Hosseini, A. (2020). "Genus Boswellia as a new candidate for neurodegenerative disorders," Iranian Journal of Basic Medical Sciences 23(3), 277-286. DOI: 10.22038/IJBMS.2020.35288.8419

Ravines, P., and Faurie, A. (1993). "The impregnation and absorption behaviour of methyl cellulose on two modern papers," in: Proceedings of the ICOM Committee for Conservation 10 $0^{\text {th }}$ Triennial Meeting, 22-27 August, Washington, DC, pp. 462-468. Saha, P., Chowdhury, S., Roy, D., Adhikari, B., Kim, J. K., and Thomas, S. (2016). "A 
brief review on the chemical modifications of lignocellulosic fibers for durable engineering composites," Polymer Bulletin 73(2), 587-620. DOI: 10.1007/s00289015-1489-y

Salim, E., Abdel-Hamied, M., Salim, S., Gamal, S., Mohamed, S., Galal, F. E. Z., Tarek, F., Hassan, R. R., Ali, H. M., and Salem, M. Z. M. (2020). "Reduction of borax / agar-based gel residues used to neutralize acidity of a historical manuscript with use of different paper barriers: Artificial ageing results," BioResources 15(3), 6576-6599. DOI: 10.15376/biores.15.3.6576-6599

SAS (2001). User Guide: Statistics (Release 8.02), SAS Institute, Cary, NC.

Sehlstedt-Persson, M. (2005). Properties of Solid Wood: Responses to Drying and Heat Treatment, Licentiate Thesis, Luleå University of Technology, Luleå, Sweden.

Seo, M. S., Youn, H. J., and Lee, H. L. (2020). "Penetration control of surface sizing starch using cationic PAM and its effect on the bending stiffness of paper," BioResources 15(3), 5489-5502. DOI: 10.15376/biores.15.3.5489-5502

Shi, F., Zhao, J.-H., Liu, Y., Wang, Z., Zhang, Y.-T., and Feng, N.P. (2012). "Preparation and characterization of solid lipid nanoparticles loaded with frankincense and myrrh oil," International Journal of Nanomedicine 7, 2033-2043. DOI: 10.2147/IJN.S30085

Speight, J. G. (2018). Reaction Mechanisms in Environmental Engineering: Analysis and Prediction. Butterworth-Heinemann. DOI: 10.1016/C2013-0-16045-X

Spitzmueller, P. (1992). "Selecting a paper re-sizing agent and its concentration: A look at parchment size and photographic gelatin," in: Proceedings of the Institute of Paper Conservation Conference, 1-4 April, Manchester, United Kingdom.

Taha, A. S., Abo Elgat, W. A. A., Fares, Y. G. D., Dessoky, E. S., Behiry, S. I., and Salem, M. Z. M. (2021). "Using plant extractives as eco-friendly pulp additives: Mechanical and antifungal properties of paper sheets made from linen fibers," BioResources 16(2), 2589-2606. DOI: 10.15376/biores.16.2.2589-2606

Taha, A. S., Salem, M. Z. M., Abo Elgat, W. A. A., Ali, H. M., Hatamleh A. A., and Abdel-Salam, E. M. (2019). "Assessment of the impact of different treatments on the technological and antifungal properties of papyrus (Cyperus Papyrus L.) sheets," Materials 12(4), 1-19. DOI: 10.3390/ma12040620

TAPPI T 441 om-09 (2013). "Water absorptiveness of sized (non-bibulous) paper, paperboard, and corrugated fiberboard (Cobb test)," TAPPI Press, Atlanta, GA.

Vinçotte, A., Beauvoit, E., Boyard, N., and Guilminot, E. (2019). "Effect of solvent on PARALOID ${ }^{\circledR}$ B72 and B44 acrylic resins used as adhesives in conservation," Heritage Science 7(1), 1-9. DOI: 10.1186/s40494-019-0283-9

Xia, K., Liu, X., Wang, W., Yang, X., and Zhang, X. (2020). "Synthesis of modified starch/polyvinyl alcohol composite for treating textile wastewater," Polymers 12(2), 1-13. DOI: $10.3390 /$ polym 12020289

Zervos, S. (2010). "Natural and accelerated ageing of cellulose and paper: A literature review," in: Cellulose: Structure and Properties, Derivatives and Industrial Uses, A. Lejeune and T. Deprez (ed.), Nova Science Publishers, Inc., Hauppauge, NY.

Article submitted: July 22, 2021; Peer review completed: Aug. 28, 2021; Revised version received and accepted: Sept. 2, 2021; Published: September 9, 2021.

DOI: 10.15376/biores.16.4.7180-7204 